\title{
The InTernational CRIME OF ECOCIDE
}

\author{
MARK ALLAN GRAY*
}

\author{
INTRODUCTION
}

\begin{abstract}
And I have felt
A presence that disturbs me with the joy Of elevated thoughts; a sense sublime Of something far more deeply interfused, Whose dwelling is the light of setting suns, And the round ocean and the living air, And the blue sky, and in the mind of man ... Therefore am I still $A$ lover of the meadows and the woods, And mountains; and of all that we behold From this green earth
\end{abstract}

William Wordsworth

From earliest times, humans have demonstrated a remarkable capacity to subdue and alter their physical environment. What began as a struggle for survival became a predominance among living things, then, in wealthier societies, a relentless drive for comfort and pleasure. Even, perhaps especially, in less-developed countries (LDCs), where for many survival remains a struggle, the conquest of nature proceeds apace. "Development" is now a worldwide synonym for progress. ${ }^{1}$

It is therefore ironic that the scope and effects of human activity actually threaten our survival as a species. Scientists and politicians cannot agree on the precise causes and implications of, let alone solutions to, such international catastrophes as ozone layer depletion, global warming and species extinction. There is nevertheless growing acceptance of the notion that arrogance, ignorance and greed, combined with overpopulation and powered by technology, are responsible for such severe resource exploitation and

* LL.B. (Toronto), LL.M. (Monash). First Secretary, Australian Permanent Mission to the United Nations, New York. Former Head of the Environmental Law Unit, Legal Office, Australian Department of Foreign Affairs and Trade, Canberra. The opinions expressed in this Article are those of the author and not necessarily those of the Australian Government or Department of Foreign Affairs and Trade. The author wishes to acknowledge the advice and assistance of Associate Professor Barry Connell of Monash University, Melbourne.

1. For a thoughtful exposition of changing perceptions of development, its purposes and its real effects, see Mark Abley, Developing Doubts About "Development" and A Measure of Hope: Recipes for Rethinking How We Rank a Nation's Wealth, OTTAWA CITIZEN, Jan. 8, 1994, at A10. Abley's thesis is that development of LDCs has only made them poorer, widened domestic disparities and shown First World values as flawed. Progress, indeed, but towards what? 
environmental degradation as to menace the integrity of the very biosphere, that thin layer of earth, water and air upon which all life depends.

Such mindless destruction is immoral, an affront to humanity, nature and God. It is also economically and politically self-defeating. Unfortunately, human affairs are not ordered purely according to ethics. World financial and trade institutions, while capable of exerting influence, lack a primary environmental mandate. ${ }^{2}$ Despite raising public consciousness, diplomacy alone has failed to resolve key environmental problems. What consensus exists among nations as to what is ecologically "wrong" must be sought in the realm of public international law.

This Article demonstrates that states, and arguably individuals and organizations, causing or permitting harm to the natural environment on a massive scale breach a duty of care owed to humanity in general and therefore commit an international delict, "ecocide." 3 The Article then examines the extent to which ecocide could be considered an international crime. Ecocide is identified on the basis of the deliberate or negligent violation of key state and human rights and according to the following criteria: (1) serious, and extensive or lasting, ecological damage, (2) international consequences, and (3) waste. Thus defined, the seemingly radical concept of ecocide is in fact derivable from principles of international law. Its parameters allow for expansion and refinement as environmental awareness engenders further international consensus and legal development.

2. The International Bank for Reconstruction and Development (World Bank) has, after years of contributing to environmental degradation in LDCs, developed a leading conservation role among multilateral development banks. Reforms in 1987 included the establishment of an Environmental Department and a strategy- Environment, Growth and Development'- to ensure the integration of environmental considerations into all aspects of the Bank's operations, and national environmental action plans to encourage environmentally sound resource management in borrower states. Ibrahim F.I. Shihata, The World Bank and the Environment-A Legal Perspective, in INTERNATIONAL ENVIRONMENTAL LAW: RECENT DEVELOPMENTS AND IMPLICATIONS $\S \mathrm{H}$, at 2-9 (1991); Kenneth Piddington, The Role of the World Bank, in THE INTERNATIONAL POLITICS OF THE ENVIRONMENT: ACTORS, INTERESTS, AND INSTITUTIONS, 212, 215-20 (Andrew Hurrel \& Benedict Kingsbury eds., 1992). Since the 1992 U.N. Conference on Environment and Development, the Bank has committed U.S.\$4.4 billion in loans and credits for environmental projects, for a total portfolio of about U.S.\$9 billion. The Environment for Development, 7(1) OUR PLANET 7 (1995). The European Bank for Reconstruction and Development, founded in 1990, was the first multilateral development bank with an explicit environmental mandate in its charter. The other three have belatedly followed these leads by altering lending policies to support ecologically sustainable development and cease financing environmentally destructive projects. Michael J. Kane, Promoting Political Rights to Protect the Environment, 18 YALE J. INT'L L. 389, 408-09 (1993). None of them, however, exists specifically for the purpose of environmental protection. See Peter S. Thacher, The Role of the United Nations, in THE INTERNATIONAL POLITICS OF THE ENVIRONMENT: ACTORS, INTERESTS, AND INSTITUTIONS 183, 199-200 (1992) (describing the Global Environment Facility, which has an environmental mandate but is a program rather than a financial institution).

3. Cf. Lynn Berat, Defending the Right to a Healthy Environment: Toward a Crime of Geocide in International Law, 11 B.U. INT'L L.J. 327 (1993) (arguing for an international crime she names "geocide"). Berat's reasoning is consistent with that of this Article, but she bases geocide on a violation of a right to a healthy environment through intentional species destruction. In contrast, ecocide exists as a delict, it need not be intentional or cause species extinction, and is based on breach of a number of obligations and rights. It is supported by, but unlike geocide not dependent upon, a right to a healthy environment. 
With acceptance of the concept will come enforcement provisions and machinery; they presently lie within the realm of theory and are not extensively considered here.

\section{ECOCIDE \\ A. Damage \\ 1. Serious}

Ecocide is based upon ecological damage which is both serious and either extensive or lasting. The requisite seriousness can arise from either the scale of the harm and the numbers of people and species ultimately affected, as in the systematic nature of global rain forest destruction and the trade in endangered species; or its impact on people in terms of social and economic costs, such as those following the Chernobyl nuclear accident, or loss of unique natural assets, as in Prince William Sound after the Exxon Valdez oil spill. The requisite significance can lie, on the one hand, in vast geographical coverage or a large number of heads of damage, or, on the other hand, in the difficulty, unlikelihood or even impossibility of reversing it-conditions met, for example, by major river damming and diversion. These criteria are admittedly somewhat subjective, but generally acceptable standards could evolve through adjudication.

\section{International Consequences}

The environmental catastrophes mentioned in the preceding paragraph demonstrate the three ways in which ecocide's international requirement can be satisfied. They threaten significant interests and values of the global community, including life, health and resources vital to both. Citizens of more than one state number among their victims and perpetrators. Political, social, economic and technological considerations mean they can only be halted, reversed or prevented from recurring through international cooperation.

\section{Wasteful}

What makes ecocide morally reprehensible, and could elevate it from a mere international delict to an international crime, is the element of waste. An obvious case is Iraq's igniting of Kuwaiti oil wells during the Gulf War. In contrast, rain forest destruction, toxic waste dumping and unsustainable fishing practices result from a complex mixture of political, economic and social factors, and difficult decisions are required to stop them. They are nevertheless neither inevitable nor necessary.

Ecocide consists of deliberate acts and policies which governments, individuals and organizations perform and pursue knowing the harm they 
cause and the alternatives available. It usually produces nothing of benefit to society-although it often greatly benefits a profiteering minority-and when there are social benefits they are greatly outweighed by social costs. Ecocide squanders precious resources, precludes efficient alternatives and widens wealth disparities. It is unproductive, unsustainable and misguided. It is wasteful.

\section{B. Responsibility}

\section{Basis}

\section{a. Fault}

As explored below, responsibility for ecocide could be based upon strict liability. This standard would best encourage preventive behavior, advance the "polluter pays" and "precautionary" principles, ${ }^{4}$ and simplify issues of proof of knowledge, intent and causation. It is the purpose of this Article, however, to demonstrate the existence of ecocide under international law and to investigate whether it is an international crime, not to promote social goals, elevate international environmental law to higher standards or propose an enforcement and compensation regime. Accordingly, ecocide-the commission of a significant act or series of acts, or omission to act in a significant instance or series of instances, which causes or permits ecological damage meeting the criteria outlined above and where feasible alternatives are known to be available-is based on fault.

The act or omission can be wilful, such as the deliberate destruction of endangered species habitat or illegal use of driftnets, or failure to act to prevent them; reckless, as in exploiting resources or lending development funds without regard for the known or foreseeable risk of destruction; or negligent, as in undertaking inappropriate development projects or improperly regulating development. Even if legal under municipal law, the act or omission constitutes a breach of a duty of care owed to humanity in general and arising from a treaty, customary international law or another generally accepted international obligation.

4. The "polluter pays" principle provides that those generating pollution and waste should bear the costs of containment, avoidance or clean up. The resulting internalization in products of their cost to the environment means that such costs are reflected in prices and ultimately borne by the consumer, who will then be more likely to favor products whose creation impacts less severely upon the environment. The "precautionary principle" provides that, where there are threats of serious or irreversible environmental damage, lack of scientific certainty should not mean the postponing of measures to prevent environmental degradation. This shifts the burden of proof to those claiming their activities do not harm the environment and thus encourages use of the best available technology in advance of conclusive scientific determination of a causal link. 


\section{b. Foreseeability}

Development of the precautionary principle should eventually make it possible to argue that fault can arise from knowledge or failure to realize, where it was reasonable to do so, that the act or omission was wasteful and would produce its immediate effects, such as destruction of particular species or resources, without appreciation of the ultimate harm to global interests. International law's current state of development requires, for the existence of ecocide, knowledge or unreasonable failure to realize that the general scientific consensus is that the act or omission causes or contributes significantly to global environmental impairment, such as ozone layer depletion, climate change or destruction of biological diversity, with deleterious consequences for health, property and economic and spiritual interests. This absolute foreseeability requirement has important implications for the identification of perpetrators, as few actors other than states possess the requisite knowledge.

\section{c. Location}

Because these ultimate effects are felt internationally, for example in more skin cancer, tropical storms and species extinctions, it does not matter to the analysis of ecocide-except as to standing-whether the material damage proximate to the act or omission occurs within the perpetrator's national territory, another state, or the global commons beyond national borders.

Important issues not otherwise considered in this Article are proof of causation, apportionment of liability among co-perpetrators and the applicability of defenses such as force majeure, duress and necessity. Because ecocide presupposes knowledge of available alternatives, it is not clear that these defenses would be available as they refer, respectively, to the impossibility of conformity with an international obligation due to an irresistible force or unforeseen external event beyond the perpetrator's control; war; and safeguarding essential interests against grave and imminent peril without seriously impairing essential interests of another.

\section{Perpetrators}

\section{a. States}

States commit ecocide when their activities or policies, or their unreasonable failure to regulate activities within their jurisdiction or control, directly cause or permit ecological damage meeting the criteria outlined above. States are responsible for acts and omissions committed on their behalf or under color of their authority by government officials, organs and enterprises. Where the acts are performed by individuals or entities which, though private, are under state jurisdiction or control, state responsibility is 
neither vicarious nor complicitous; it arises directly from the failure to prevent or abate those acts through administrative and legislative guidance, regulation, enforcement and punishment.

Ecocide can arise from inappropriate planning and development policies in which environmental impact assessment is rhetorical or marginal, and from the absence or inadequacy of protective administrative or legislative structures. It is the delictual refusal to incorporate the recognition and safeguarding of essential interests of the international community into national policy. Contributing to it is a lack of government leadership in raising and heeding domestic environmental consciousness, and in cooperating with other governments to solve international environmental problems jointly.

Where economic and political circumstances limit the options of LDCs, they do not necessarily commit ecocide in attempting rapid but ecologically destructive industrial development. They may do so, though, where they incorrectly (the author submits) insist that the balance between environment and development is entirely a sovereign national concern, regardless of international consequences, and where they accordingly refuse international assistance and encourage others to do the same. Conversely, developed countries (DCs) can commit ecocide by contributing to environmental destruction in LDCs through facilitation or inadequate regulation of harmful activities by their nationals there. Especially egregious are unsustainable development assistance projects which enrich the donor or its domestic interests, or constitute relocation of polluting industries under the guise of investment and technology transfer. Just as damaging may be projects run by multilateral agencies and negligently overseen by donors.

The most fundamental First World leadership failing, underlying many instances of ecocide and possibly itself constituting ecocide, is the refusal to examine the values and changes imposed upon poorer societies through development. "Development" has been defined as a process of enclosure, by which common wealth is transformed into scarce resources subject to private exploitation. So-called "development assistance" sometimes presupposes the superiority of donor states' values, like perpetual economic growth and limitless consumption, and the legitimacy of the global cost. While improved levels of infant mortality, literacy and life expectancy are noble goals, they cannot last and indeed will decline when achieved through the impairment of natural processes. In any event, they have not come to the indigenous and other peoples of many LDCs, for whom "development" has meant a lower standard of living and the undermining of ways of life far more sustainable than those of the donors. ${ }^{6}$

5. A Measure of Hope, supra note 1 , at $\mathrm{A} 10$.

6. There are strong indications that citizens of DCs, including those on the conservative side of the political spectrum, for example, in the United States, are increasingly embracing sustainable development values and accepting the need for limits on economic growth. Eugene Linden, Economists and Environmentalists: Ships Passing in the Night, Lecture at the Carnegie Council on Ethics and International Affairs, New York (June 4, 1996). 
b. Individuals

In addition to rendering their states liable for ecocide through their actions and omissions committed in an official capacity or under color of authority, individuals will, with the development of international law, be seen as committing ecocide in their own right. They will do so independently of their states or, acting officially or with their states' knowledge and unreasonable failure to intervene, simultaneously; in either case they will be responsible qua individuals. This Article does not seek to establish that individuals do commit ecocide under current international law, only that a basis for their responsibility exists.

The International Court of Justice (ICJ) held somewhat tautologically in Reparation for Injuries" that a "subject" of international law is an entity capable of possessing international rights and duties and of maintaining its rights by bringing international claims. ${ }^{8}$ Many publicists, observing that international law grants rights and imposes duties on individuals, and that there is no rule establishing that individuals are not subjects of international law, claim that they are. ${ }^{9}$ Narrow recognition of individual responsibility under international law ${ }^{10}$ and ecocide's serious damage and absolute foreseeability requirements nonetheless limit the scope for individual commission. Possible culprits are senior politicians and government officials in states where ecocide-type harm occurs or which have jurisdiction or control over corporations and multilateral development banks causing the harm, executives of those corporations and banks, and highly influential individuals running harmful projects or investing in them on a large scale.

\section{c. Organizations}

Although many entities, national and international, private and public, knowingly play a direct role in cases otherwise meeting the criteria set out above, only a few have international legal personality, cause sufficient damage, and meet the absolute foreseeability requirement so as to be culpable of ecocide.

Were corporations recognized as having international legal personality, obvious culprits would be those running destructive and inefficient rain forest logging operations, defying legislation restricting cutting, and exporting and importing while evading local taxes; fishing interests maximizing profits through illegal catches or techniques; industrial and pharmaceutical manufacturers ignoring restrictions on plant collection and eradicating species instead

7. Reparation for Injuries Suffered in the Service of the United Nations, 1949 I.C.J. 174 (Apr. 11).

8. Id. at 179. 1990).

9. See Ian Brownlie, Principles of Public International Law 37-67, 581 (4th ed.

10. See Malcolm N. Shaw, International LaW 178-81 (1991). 
of harvesting them; transporters of oil and toxic substances in unsafe vessels; and utilities generating power with faulty or improperly run nuclear facilities. Other corporate candidates would be hamburger chains buying rain forest beef at artificially low prices to increase profit margins infinitesimally; companies spouting "green" rhetoric while bribing officials, threatening opponents and disregarding planning and pollution controls; suppressors of more efficient industrial or energy producing processes which threaten their monopolies; and, finally, the banks financing it all.

Multilateral development banks could be seen as committing ecocide by sponsoring unnecessary megaprojects and failing to integrate environmental considerations into their economic planning, instead of fulfilling their mandate to assist ecologically sustainable development (ESD) and exerting their influence over host governments to encourage environmental impact assessment. Multilateral development banks, certain international associations ${ }^{11}$ and governmental groupings, ${ }^{12}$ and United Nations agencies ${ }^{13}$ are recognized as having international legal personality. ${ }^{14}$ They and, with refinement of the ecocide concept and recognition of a wider range of subjects of international law, other kinds of organizations such as interest groups, which indirectly cause the requisite damage through self-interest or a neglected mandate, could be identified as culprits.

\section{Rights Violated}

This Article demonstrates that certain instances of environmental destruction breach an international duty of care, largely through the violation of internationally recognized human rights. It does not advocate their extension to new human rights or to non-human beneficiaries; but it will consider emerging rights: to a healthy environment, to development, and of non-human entities.

\section{Human}

Ecocide can be established on the basis of the two most fundamental human rights alone: the right to life and the right to health. By diminishing, for example, earth's vital and stressed capacities to produce oxygen, food and medicines, to block harmful radiation and to maintain stable climates and the

11. See Barbara J. Bramble \& Gareth Porter, Non-Governmental Organizations and the Making of U.S. International Environmental Policy, in THE INTERNATIONAL POLITICS OF THE ENVIRONMENT: ACTORS, INTERESTS, AND INSTITUTIONS 313, 341-46 (1992) (outlining the failure of the International Tropical Timber Organization to replace the current free trade regime with sustainable logging programs).

12. For example, the OECD, the European Union, the Group of Seven Industrialized Nations and the Organization of African Unity.

13. See Mark A. Gray, The United Nations Environment Programme: An Assessment, 20 ENVTL. L. 291 (1990).

14. BROWNLIE, supra note 9 , at $37-67,680-707$. 
often-fragile social, political and economic orders that depend upon them, culprits contribute directly and substantially to causing individual deaths in LDCs, impairing human health globally and even threatening the survival of the species. The destruction and its effects, however, contribute to the violation of other rights throughout the developing world: security of the person; protection of the family and property; freedom from hunger; social security; an adequate standard of living; and a safe work environment; as well as human dignity, infringed along with cultural and religious rights in the case of aboriginal people by the destruction of their societies, institutions, livelihoods and identities, and in the case of people everywhere by the severing of spiritual and aesthetic links to wilderness and the diminution of humanity as a part of nature. It can be argued that equality rights are violated, both as between peoples within an affected country, viz., disenfranchised indigenous people and rural poor as compared to unaffected or benefiting urban elites, and as between those in LDCs who gain no benefit from the exploitation of their resources but suffer the effects of impoverishment and those in DCs who grow correspondingly rich without making sacrifices. It may also be that two collective rights are threatened: aboriginal self-determination, and everyone's right to a social and international order in which all other rights and freedoms can be fully realized.

Two so-called "third generation" or "solidarity" rights are to a healthy environment and to development. ${ }^{15}$ Neither is fully accepted under international law; but both are emerging as recognized interests which could eventually gain human rights status as, it is here predicted, Eastern concepts of duty and community rights seize a larger role in the development of international human rights law. ${ }^{16} \mathrm{~A}$ right to enjoy and use a healthy environment, one that is clean, ecologically balanced and protected, and whose physical, social and cultural elements are adequate for both individual well-being and dignity and collective development, can be seen as necessarily

15. See Human rights based on solidarity, G.A. Res. 148, U.N. GAOR, 44th Sess., Supp. No. 49, at 226, U.N. Doc. A/44/49 (1990); Noralee Gibson, The Right to a Clean Environment, 54 SASK. L. REV. 5 (1990) (discussing the elaboration of a right to a healthy environment and an explanation of the three categories of human rights: civil and political; economic, social and cultural; and solidarity or collective). First generation rights-those protecting individual freedoms against state intrusion-have been analogized to the French Revolution's "liberté," second generation rights - those associated with welfare state obligations-to "égalité," and third generation collective rights to "fraternite" or "solidarité." Stephen P. Marks, Emerging Human Rights: A New Generation for the 1980s?, 33 RUTGERS L. REV. 435, 441 (1981). See Philip Alston, $A$ Third Generation of Solidarity Rights: Progressive Development or Obfuscation of International Human Rights Law? 29 NETH. INT'L L. REV. 307 (1982). A right to a healthy environment can be seen as both individual and collective. J. Waldron, Can Communal Goods Be Human Rights? 28 EUR. J. Soc. 296 (1987).

16. See W. Paul Gormley, The Legal Obligation of the International Community to Guarantee a Pure and Decent Environment: The Expansion of Human Rights Norms, 3 GEO. INT'L ENVTL. L. REV. 85, 95-105 (1990). See also African Charter on Human and Peoples' Rights, OAU Doc. CAB/LEG/67/3/Rev.5 (1981), reprinted in 21 I.L.M. 59 (1982) (specifying specific rights and duties) [hereinafter African Charter]. 
underlying all other rights. ${ }^{17}$ A right to development, entailing a sustainable and constantly improving livelihood for a particular population, would be both a basis for realization, and the evolutionary outcome, of all other rights. ${ }^{18}$

In the process of violating the rights listed above, culprits trample on the victims' procedural rights: access to information; environmental assessment as an integral part of planning; participation in judicial and administrative proceedings; and effective domestic remedies and compensation. It is important to note, however, that while these rights are crucial tools in the battle against it, their denial does not constitute ecocide. ${ }^{19}$

\section{Other}

Ecocide can be proven on the basis of the internationally recognized human rights listed above. While it does not depend upon the acceptance of new rights or their vesting in non-human entities, its evolution will accelerate and in turn be accelerated by the evolution of interests or "rights"-defined by the Oxford English Dictionary as, inter alia, things "one may legally or morally claim," and which are "morally or socially correct or just"-in the broadest sense. It is therefore worth briefly exploring the status of interests held by non-human entities and harmed by activities otherwise-and perhaps eventually accordingly-constituting ecocide.

States have rights as against other states that are the source of transboundary pollution. ${ }^{20}$ While this Article does not concentrate on states as victims of ecocide, their rights under international law are essentially held on behalf of their citizens ${ }^{21}$ and therefore form part of the analysis below. Any

17. Janusz Symonides, The Human Right to a Clean, Balanced and Protected Environment, 20 INT'L J. OF LEGAL INFO. 24, 28-29 (1992). This author argues that this right "is already wellestablished." Id. at 39 . Berat maintains that it has become part of customary international law. Berat, supra note 3 , at 3.

18. Russel L. Barsh, The Right to Development as a Human Right: Results of the Global Consultation, 13 HUM. RTS. Q. 322 (1991) (discussing recent U.N. activities and General Assembly resolutions concerning the emerging right to development and explaining that it is not so much a right to improvement in material conditions as local empowerment through rights of participation and consultation in economic and social decision-making).

19. Kane, supra note 2, at 389 (outlining how these political rights can be employed to protect the environment).

20. This aspect of international environmental law is discussed in Section 2(B).

21. Theorists like Kelsen see the state as comprised of individuals, the true and sole subjects of international law. State rights and duties are therefore really individual rights and duties. J.G. STARKE, INTRODUCTION TO INTERNATIONAL LAW 59 (1989). Note, however, the dictum of the Permanent Court of International Justice. "It is an elementary principle of international law that a State is entitled to protect its subjects, when injured by acts contrary to international law committed by another State, from whom they have been unable to obtain satisfaction through the ordinary channels. By taking up the case of one of its subjects ... a State is in reality asserting its own rights-its right to ensure, in the person of its subjects, respect for the rules of international law." Mavrommatis Palestine Concessions (Jurisdiction), 1924 P.C.I.J. (Ser. A) No. 2 , at 12 . 
state can claim a legal interest in ecocide destruction. ${ }^{22}$ In particular, LDCs robbed of their development potential by environmental degradation could eventually be considered ecocide victims with recognition of a collective right to development.

The natural world's beauty, complexity and fragility suggest that it and its components in their own right have interests worthy of protection, or at least that our liberty to exploit nature is not limited solely by the claims of other people. Radical theorists argue for recognition of legal rights of nature or the "environment, ${ }^{9,23}$ which includes non-living elements. Others limit their claim to living things ${ }^{24}$ or specifically to animals. ${ }^{25}$ A convincing argument, for instance, is made that whales have an emerging right to life, which right will gain recognition as statist and positivist conceptions of international law give way to humanist and natural law conceptions. ${ }^{26}$ Such rights do not currently enjoy recognition under international law. ${ }^{27}$ Nevertheless, every element of nature is unique and has inherent dignity, and therefore warrants respect regardless of its value to man. Being different from humans does not mean being less worthy of respect. All living things are vulnerable and, in the case of fauna, sentient, and therefore deserving of protection. These interests, it is here predicted, will go beyond the moral and take on legal characteristics as human understanding of our world improves and as the Eastern concept of duty influences the elaboration of international human rights law. Ecocide can be envisioned as not just the breach of a legal duty of care, but the violation of a duty to protect. This construct would serve to protect the environment better than the human rights basis because it would not depend upon acceptance of non-human rights and its identification would focus on the culprit rather than the victim.

These interests are also relevant to our human-rights based model of

22. See Section I(D).

23. Christopher D. Stone, Should Trees have Standing? Toward legal Rights FOR NATURAL ObJECTS (1974); James A. Nash, The Case for Biotic Rights, 18 YALE J. INT'L L. 235 (1993).

24. G.E. Varner, Do Species Have Standing?, 9 ENVTL. ETHICS 57 (1987).

25. PETER Singer, ANIMAL LiBERATION (1975).

26. Anthony D'Amato \& Sudhir K. Chopra, Whales: Their Emerging Right to Life, 85 AM. J. INT'L L. 21 (1991). But Cf. Holmes Rolston, Rights and Responsibilities on the Home Planet, 18 YALE J. INT'L L. 251, $257-59$ (1993) (arguing that while animals have intrinsic values that may form the basis for a human ethic, they do not possess "rights" per se).

27. Juristic bases for environmental protection will be much strengthened at such time as these rights are recognized because basing that protection upon human rights and needs entails unfortunate compromises. See D'Amato \& Chopra, supra note 26, at 50-61. Note that, although the author foresees international legal recognition of rights of nature, there is vigorous debate about whether conventional legal and moral arguments can support such rights. See, e.g., John Livingston, Rightness or Rights?, 22 OsGOODE HALL. L.J. 309 (1984). James W. Nickel, The Human Right to a Safe Environment: Philosophical Perspectives on Its Scope and Justification, 18 YALE J. INT'L L. 281-82 (1993) (arguing "rights should not be the dominant normative concept of environmentalism. It is better to phrase most environmental discourse in terms of environmental goods, of respect for and responsibilities towards nature, and of obligations to future generations."). 
ecocide, as their impairment affects man. The degradation of nature offends human dignity and distresses many, including the author, at a spiritual level because nature is a part of humanity. More fundamentally, the cohesion and interdependence of all living things mean that we are harmed as a part of nature (much as a state's right to complain about transboundary pollution is really the collective right of its citizens). As one publicist put it, "the integrity of nature is also the integrity of the human species as part and product of nature."28 To destroy nature is to destroy ourselves.

Human rights not yet, but arguably destined to be, generally accepted, which are violated by environmental destruction on the ecocide scale, are those of future generations. The concept of intergenerational equity, discussed below, means that as-yet unborn humans could eventually, and others on their behalf could now, complain that they too suffer ecocide's violations of human rights. Furthermore, humanity is now failing any duty it might have to balance its present gains from and sacrifices for earth's resources with those of future generations. For the purposes of this Article and in view of the theoretical problems posed by recognition of intergenerational equity and rights of future generations, it is sufficient to note that living persons, particularly in LDCs, are affected: their rights to survival at the family, community and species levels and to the satisfaction of handing over the earth in a healthy condition to their and others' descendants are infringed by ecocide.

\section{Standing}

As stated, this Article is not concerned with processes and institutions for the prosecution of ecocide. It is submitted that establishing its theoretical underpinnings presents a greater intellectual and scholarly challenge and, in any event, a logical antecedent. Furthermore, others have published detailed and convincing arguments and proposals for the establishment, for example, of an international criminal court ${ }^{29}$ and even an international court for the

28. Nash, supra note 23, at 249.

29. See William N. Gianaris, The New World Order and the Need for an International Criminal Court, 16 FORDHAM INT'L L.J. 88 (1992); F. Malekian, "The Principal Function of an International Criminal Tribunal," delivered at U.N. Int'l Inst. of Higher Studies in Criminal Sciences World Conference on the Establishment of an International Criminal Court to Enforce International Criminal Law and Human Rights, Siracusa, Italy, Dec. 2-5, 1992 (on file with author); BENJAMIN R. CIVILETTI ET AL., REPORT OF THE TASK FORCE ON AN INTERNATIONAL CRIMINAL COURT OF THE AMERICAN BAR ASSOCIATION (1994); M. CHERIF BASSIOUNI, DRAFT INTERNATIONAL CRIMINAL CODE AND DRAFT STATUTE FOR AN INTERNATIONAL CRIMINAL TrIBUNAL (1987); Tze-chung Li, Prospect and Problems in the Creation of an International Criminal Jurisdiction (1966) (Ph.D. thesis, University of Michigan (Ann Arbor)), microfilmed on University Microfilms International (discussing the history of attempts to establish, and proposals for, an international criminal court and code). Concerning the work of the International Law Commission, see Report of the Commission to the General Assembly on the work of its forty-sixth session, U.N. GAOR, 49th Sess., Supp. No. 10, U.N. Doc. A/49/10 (1994) [hereinafter Report on the forty-sixth session]; Report of the Commission to the General Assembly on the work of its forty-fifth session, [1993] 2 (II) Y.B. Int'l L. Comm'n, U.N. Doc. 
environment. ${ }^{30}$ The only aspect of locus standi, or standing, to complain of ecocide which is relevant here, therefore, is who should have it.

As mentioned in the preceding section, states have rights as against others which are the sources of transboundary pollution. Section II(B) demonstrates that states have standing under treaty and customary international law, including that of human rights.

Certainly, every individual should have standing. Traditional limitations, based on the principle that a claimant must have suffered direct injury to a fundamental interest and the policy that the mandated defenders of the public interest must not be superseded and the courts inundated, ${ }^{31}$ do not apply. The principle is not an obstacle because, as demonstrated above, ecocide is a direct assault on the most fundamental interests of every individual on the planet. Its effects are more apparent in the case of indigenous people and the poor in LDCs; but that relates to proof and perhaps priorities for action to stop ecocide. As for the policy, it is submitted that-as is increasingly being recognized at the municipal legal level ${ }^{32}$-more important policies such as species survival and ESD should predominate; besides, "floodgates" concerns also relate to enforcement. It may be that citizens of states party to the Optional Protocol to the International Covenant on Civil and Political Rights $^{33}$ already have standing in the prescribed circumstances to complain in their own right of ecocide. ${ }^{34}$

Developments in municipal and international law, ${ }^{35}$ and the collective nature of key interests at stake, point to states, and possibly international and non-governmental organizations (NGOs), as logical "next friends" to bring claims on behalf of individuals lacking the resources to do so themselves. Limiting standing to such entities, particularly to states on behalf of their citizens against other states, could in fact be the answer to the floodgates argument and the vexed question of sovereignty. Less clear is in what other

A/CN.4/SER.A1993/Add.1(Part 2), U.N. Sales No. E.95.V.4 (Part 2) [hereinafter Report on the forty-fifth session]; Robert Rosenstock, The Forty-fifth Session of the International Law Commission, 88 AM. J. INT'L L. 134 (1994).

30. J. Amedeo Postiglione, A More Efficient International Law on the Environment and Setting Up an International Court for the Environment Within the United Nations, 20 ENVTL. L. 321 (1990); Geoffrey Palmer, New Ways to Make International Environmental Law, 86 AM. J. INT'L L. 259, 278-79 (1992). See also URUGUAYAN GUIDELINES FOR A DRAFT INTERNATIONAL Environmental CODE, U.N. GAOR 2d Comm., 47th Sess., Agenda Item 79, U.N. Doc. A/C.2/47/9 (1992).

31. The "floodgates" argument, that is that allowing some cases of a particular type will cause an uncontrollable influx. Section $\operatorname{II}(A)(1)$ touches upon standing as an aspect of nuisance law.

32. Particularly in the United States. Varner, supra note 24 , at 57.

33. Optional Protocol to the International Covenant on Civil and Political Rights, Dec. 19, 1966, 999 U.N.T.S. 171, 6 I.L.M. 383. See also European Convention for the Protection of Human Rights and Fundamental Freedoms, Nov. 4, 1950, art. 25, 213 U.N.T.S. 221, 236, 238 (according a right of petition to aggrieved individuals, non-governmental organizations, and groups).

34. If so, it is not yet generally recognized.

35. See infra Section II(A) \& (B). 
circumstances non-individuals would be accorded standing. International law does recognize certain legal interests as providing standing to states to complain about wrongs suffered by people generally, and not specifically by their own citizens. ${ }^{36}$ Ecocide, it is submitted, as a violation of fundamental human rights, qualifies. Were any of the other non-human entities described in section $\mathrm{I}(\mathrm{C})(2)$, or future generations, recognized as having rights violated by ecocide, they would require a "next friend." This could be a state, instituting an actio popularis, an institution mandated to make claims, or a conservation organization acting on its own initiative. ${ }^{37}$

\section{ANALYSIS}

\section{A. Municipal Law}

It is beyond the scope of this Article to examine municipal environmental law comprehensively. Parallel developments and cross-fertilization between municipal, particularly Anglo-American, law and the international law establishing ecocide nevertheless render coverage of certain elements instructive.

\section{Tort}

The origins of the common law pertaining to the environment lie in medieval English law protecting the use and enjoyment of private land. Individuals could bring private nuisance actions against those, for example operators of a factory, causing damage to, or unreasonable interference with, their use or enjoyment of their land, typically with smoke, noise or effluent. Private nuisance depends upon direct injury to the interests of the plaintiff as owner or occupier of the land. This limits not only standing but also the kind of environmental harm which may be the subject of an action. Physical damage, such as the killing of trees by noxious fumes, and measurable interference with comfort, as by unpleasant smells or the blocking of light, qualify; aesthetic and other intangible values seldom do. Tortfeasors are

36. See infra Section II(B).

37. The World Commission on Environment and Development advocates NGOs' being granted standing to act on behalf of individuals and groups whose environmental rights are violated. William A. Shutkin, International Human Rights Law and the Earth: The Protection of Indigenous Peoples and the Environment, 31 VA. J. INT'L L. 479, 503-04 (1991). See also David S. Rubinton, Toward a Recognition of the Rights of Non-States in International Environmental Law, 9 PACE ENVTL. L. REV. 475, 481 (1992) (referring to one such NGO, the Center for International Environmental Law, which aims to bring environmental suits before the ICJ); Edith Brown Weiss, The Planetary Trust: Conservation and Intergenerational Equity, 11 ECOLOGY L.Q. 495, 565-66 (1984) (presenting ideas for the legal representation of future generations). Varner explores the need for and growing acceptance of standing's being granted to non-human entities in U.S. environmental litigation. Varner, supra note 24, passim. See also Harold O. Hughes, Who's Standing? Problems With Inanimate Plaintiffs, 4 ENVT'L L. 315 (1974) (examining efforts by the Sierra Club to gain acceptance of standing for environmental "objects" in U.S. courts). 
strictly liable.

Three other traditional causes of action assign liability for environmental harm in different ways. The tort of trespass also protects an interest in land-exclusive possession-and, though narrowly interpreted, ${ }^{38}$ has been used successfully against polluters. ${ }^{39}$ As with nuisance, fault need not be proven; unlike nuisance, trespass does not require substantial or special injury, nor must it involve a balancing of legitimate uses of land. The rule in Rylands v. Fletcher, ${ }^{40}$ though originally based on damage to interests in land, has been extended to cover personal injury. ${ }^{41}$ An extension of the Roman law maxim sic utere tuo ut alienum non laedas (use your property so as not to injure that of another), it holds strictly liable those who bring or accumulate on their land anything dangerous which escapes and causes damage. Covering only those polluting activities outside "natural" or common use of the land, the rule is the precursor to international law governing ultrahazardous activities. Finally, independent of any interests in land, there is the tort of negligence. Unlike the torts described above, negligence requires fault, through breach of a duty of care, and foreseeable damage. Like nuisance, it involves a balancing of activities on the basis of reasonableness. Damage, to person or property, is physical. Despite the consequently narrow range of environmental harm covered, negligence suits have been successful against industrial polluters. ${ }^{42}$

The most significant common law action relevant to environmental harm, and the one most closely resembling ecocide, is public nuisance, or interference with public interests.

A public nuisance is ... so widespread in its range or so indiscriminate in its effects that it would not be reasonable to expect one person to take proceedings on his own responsibility to put a stop to it, but that it should be taken on the responsibility of the community at large. ${ }^{43}$

Reflecting the action's criminal origins, suits are usually brought by the Attorney General on behalf of the public, and attempts by individuals and conservation groups to protect the environment through "citizen suits" have met with judicial resistance, premised on standing but motivated by floodgates concerns. Standing has long been granted to those suffering a direct, substantial injury or loss different in both kind and degree from that suffered by the public generally. Although not required to demonstrate an

38. For example, in Esso Petroleum Co. Ltd. v. Southport Corporation, 3 All E.R. 864 (1955), A.C. 218 (H.L. 1956) (U.K.).

39. William H. Wilson, Nuisance As Modern Mode of Land Use Control, 46 WASH. L. REV. 47, 114-16 (1970).

40. Rylands v. Fletcher, 3 L.R. 330 (H.L. 1868) (U.K.).

41. Julian C. Juergensmeyer, Control of Air Pollution Through the Assertion of Private Rights, 1967 DUKE L.J. 1126, 1151.

42. Id. at 1142-51.

43. Attorney-General v. PYA Quarries Ltd., 2 Q.B. 169, 191 (Eng. C.A. 1957). 
affected interest in land, plaintiffs once found this tort as restricted in utility as those described above because of the difficulty of proving a special interest, something more than "a mere intellectual or emotional concern . . . [or a] belief, however strongly felt, that the law . . should be observed." "44 As community attitudes shift in favor of citizen empowerment to enforce higher standards of environmental quality and conservation, judicial formulations of standing have broadened to include, for example, aboriginal cultural and spiritual interests ${ }^{45}$ and conservation groups advocating and participating in resource management strategy. ${ }^{46}$

\section{Statute}

The same shift in community attitudes has led to a proliferation of environmental protection laws and, in reaction to the common law restrictions outlined in the previous section, statutory provisions granting standing for citizen suits. Moving beyond the narrow common law emphasis on protecting private property interests and assigning liability for direct injury caused by specific occurrences, statutes sought initially to regulate polluting and other activities detrimental to public health, and then to preserve the environment itself so as to maintain quality of life for present and future generations. ${ }^{47}$ Today, comprehensive legislative regimes in, for example, the United States and Australia protect air, soil and water against pollution, and natural resources and ecosystems against excessive exploitation. Accelerating the process begun under the common law of public nuisance, these laws are increasingly drafted and interpreted to empower citizens to ensure they are enforced. ${ }^{48}$

Such statutes contain procedural elements relevant to ecocide. They establish degrees of offence, ranging from fault-based-for which wilful or negligent acts or omissions must be proven-to strict liability offenses, the most serious of which entail absolute liability. ${ }^{49}$ They cover public and

44. Australian Conservation Foundation v. Commonwealth of Australia, 146 C.L.R. 493, 530-31 (1980) (Austl.).

45. Onus v. Alcoa of Australia Ltd., 36 A.L.R. 425 (1981) (Austl.).

46. Australian Conservation Foundation v. Minister for Resources, 19 A.L.D. 70 (1989) (Austl.).

47. Brian Robinson, Address at the Australian Centre for Environmental Law (Sept. 1, 1993), in ENVIRONMENTAL CRIME 9 (Neil Gunningham et al. eds., 1995). See generally GERRY Bates, ENVIRONMENTAL LAW in Australia (3d ed. 1992).

48. David Mossop, Address at the Australian Centre for Environmental Law (Sept. 1, 1993) in ENVIRONMENTAL CRIME, supra note 47, at 245.

49. Each legislative regime, of course, is different. Arguably the most advanced Australian model is the Environmental Offenses and Penalties Act, No. 150 (1989) (N.S.W.), under which the wilful or negligent behavior required for tier one offenses includes wilful blindness or recklessness and entails both a culpable act and awareness that it will, or is likely to, harm the environment. Id. art. 5(1). The Environment Protection Act, No. 8056 (1970) (Vict.), bases its most serious offenses on intention, recklessness or negligence. The U.S. Comprehensive Environmental Response, Compensation and Liability Act, in contrast, imposes strict liability. 42 U.S.C. § 9601 (1995) [hereinafter Superfund legislation]. See Jennifer Norberry, Address at 
private organizations, and hold the organization responsible for the actions of its directors, managers and even lenders while imposing personal liability on the individuals involved. ${ }^{50}$ Liability attaches for contribution to an offence and for clean-up costs relating to actions legal when performed.

More important, these statutes are integral to the evolution and recognition of principles lying at the root of ecocide and discussed in the international law context in Section II(B). Whether implicitly or, as in Australia, explicitly, modern environmental legislation aims at ESD, a term variously defined and variably interpreted but essentially meaning effective integration of environmental and economic considerations in decision-making. As is apparent from other definitions of ESD, in its broadest sense it encompasses preservation and enhanced quality of life for individuals, the community, future generations, non-humans, and the natural environment itself:

Development that allows the present generation to meet its needs and aspirations whilst not compromising the ability of future generations to do likewise. ${ }^{51}$

Using, conserving and enhancing the community's resources so that ecological processes, on which life depends, are maintained, and the total quality of life, now and in the future, can be increased. ${ }^{52}$

A process of transformation in the economy, the society and the environment whereby progress is made towards the achievement of a society which offers each person a full and satisfying life and ensures that non-human life, in its full diversity, is respected and can continue to flourish and survive indefinitely. ${ }^{53}$

These objectives are analyzed on the basis of key principles, of which those relevant to this article can be summarized thus: improvement in the qualitative dimension of human welfare; conservation of biological diversity and ecological integrity; efficient, sustainable resource use and waste minimization; proper valuation of natural assets and the costs of using and damaging them (including the polluter pays principle); the precautionary

the Australian Centre for Environmental Law (Sept. 1, 1993), in ENvironmENTAL CRIME, supra note 47, at 123 (regarding Australian state legislation); Philip Clifford \& Sharon Ivey, Address at the Australian Centre for Environmental Law (Sept. 1, 1993), in ENVIRONMENTAL CRIME, supra note 47, at 57; Sanford E. Gaines, International Principles for Transnational Environmental Liability: Can Developments in Municipal Law Help Break the Impasse?, 30 HARV. INT'L L.J. 311 (1989) (discussing bases of liability in Australian, U.S., English and Canadian environmental legislation).

50. See, e.g., Environmental Offenses and Penalties Act, supra note 49, §10. See also Superfund legislation, supra note 49; Matthew Goode, Address at the Australian Centre for Environmental Law (Sept. 1, 1993) in ENVIRONMENTAL CRIME, supra note 47, at 97.

51. Australian Bureau of Statistics, STRIKING A BALANCE! AUSTRALIA's DEVELOPMENT AND CONSERVATION 130 (1992) (quoting the Australian Conservation Foundation/World Wildlife Fund ESD Project Unit definition, which is based on the World Commission on Environment and Development definition of "sustainable development").

52. Id. (quoting ESD: A Commonwealth Discussion Paper, June 1990).

53. Id. (quoting Philip Sutton of the Victorian Office of the Environment, March 1991). 
principle; social equity and community participation; and maintenance or enhancement of the health, diversity and productivity of the environment for the benefit of future generations (intergenerational equity). ${ }^{54}$ Some are still at the stage of rhetoric, but others are enshrined, in varying degrees, in legislation. While it is not intended here to cover the relevant legislation exhaustively, it is instructive to identify certain provisions indicative of trends.

The qualitative dimension of human welfare, or quality of life, relates to both the right to life and the right to a healthy environment. The former falls within the province of human rights legislation and has not, to the author's knowledge, received recognition in the environmental legislation of common law states. The latter is explicitly recognized by, for example, Canadian and U.S. legislation, and even a number of U.S. state constitutions, and is implicit, though not absolute, in the standing accorded individuals to enforce environmental protection laws. ${ }^{55}$ A concern for quality of life also underlies the many statutory references to aesthetic values. ${ }^{56}$ Conservation of biological diversity and ecological integrity is an explicit objective of most environmental statutes, for example Queensland's Local Government (Planning and Environment) Act ${ }^{57}$ which like certain others seems intended to protect nature for its intrinsic value and even in its own right. ${ }^{58}$ Waste minimization and the polluter pays and precautionary principles are increas-

54. These principles are broken down and discussed in Philip Toyne, The Environment Movement and Its Role in Changing Australian Society, Charles J. Latrobe Memorial Lecture (1990) (unpublished).

55. See Symonides supra note 17 , at 27 . Note that a "right to a healthful environment" appeared in the draft, but not the final, version of the U.S. National Environmental Policy Act, 42 U.S.C. § 4321 (1995); Varner, supra note 24, at 64.

56. E.g., NSW's Environmental Offenses and Penalties Act, supra note 49; Environment Protection Act, supra note 49; Local Government (Planning and Environment) Act, No. 61 (1990) (Queensl.); Heritage Commission Act, No. 57 (1975) (Austl.). See Douglas O. Linder, New Direction for Preservation Law: Creating an Environment Worth Experiencing, 20 ENVTL. L. 49 (1990) (concerning U.S. legislative protection of aesthetics).

57. Planning and Environment Act, supra note 56. See the Act's definition of "environment." See also the Australian Commonwealth-State Intergovernmental Agreement on the Environment (1992) (Austl.), which, while not legislation itself, is a framework for Australian environmental legislation.

58. See the definition of "environment" in the Environment Protection Act, No. 87 (1986) (W.A.); Varner, supra note 24, at 59 (assessing de facto legal rights of species under the U.S. Endangered Species Act of 1973); Linder, supra note 56, at 49 (concerning U.S. legislation benefiting "other life forms.") Although its Environmental Defender, D.E. Fisher, has said that "the environment can have no legal rights as an institution, because the environment does not exist as an institution within the law. It may be the beneficiary of other institutions but it has no rights in its own sense ...." Queensland Electoral and Administrative Review Commission, Public Hearings Record of Proceedings, 948 (1992-93) (Queensl.), Queensland's proposed bill of rights contains an "offenses against the environment" provision premised on the community rights concept but considered indicative of growing recognition of rights inherent in the environment. Peter Breen, Address at Australian Centre for Environmental Law (Sept. 1, 1993) in ENVIRONMENTAL CRIME, supra note 47, at 259. 
ingly mentioned..$^{59}$ Social equity and community participation are inadequately defined and potentially far-reaching principles. They can nevertheless be read into statutory references to "sense of community" and "social groupings"61 and they clearly influence citizen suit provisions. Even intergenerational equity, a relatively radical principle as it does not directly concern living voters, is recognized by such statutes as the Australian Heritage Commission Act of 1975.

ESD and related principles have gained support in other legal systems as well. A growing number of national constitutions of both developed and developing countries in Europe, Latin America, Africa, and Asia explicitly recognize rights to a healthy environment and to conservation of natural resources, some imposing a direct obligation on the state and even on citizens to enforce them. ${ }^{62}$ A range of legislative provisions supports these rights ${ }^{63}$

59. E.g., Environment Protection Act, No. 76 (1993) (S.A.). See Australian Intergovernmental Agreement on the Environment, supra note 57, sec. 3.5.1; Robert J. Fowler, Addressing the Brown Issues-Recent Trends and Developments in Environmental Protection Law and Policy in Australia, Address at Environmental Outlook Conference (Nov. 10, 1993) (unpublished) (discussing environmental risk assessment, a precautionary concept); and the polluter pays provisions of the Superfund legislation, supra note 49. An interesting product of the growing emphasis on improved resource valuation is U.S. "right to pollute legislation," which establishes markets for unused pollution "credits" as a financial incentive for industry to reduce emissions. This concept can be seen as transforming public property-for example, clean air-into private property and sanctioning pollution.

60. Planning and Environment Act, supra note 56.

61. Environment Protection (Impact of Proposals) Act, No. 164 (1974) (Austl.). Alan S. Miller, Address at Environmental Outlook Conference (Nov. 10, 1993) (unpublished) (discussing "environmental justice" as regards the unequal sharing of environmental costs across communities).

62. Government of Italy, Introductory Document Prepared for Forum on International Law of the Environment, Siena (April 1989); New Directions in Environmental Legislation and Administration Particularly in Developing Countries (UNEP/Nairobi), 1989, at 10; Michael Holm, An Overview of Environmental Regulation in Asia, Address at Environmental Outlook Conference (Nov. 10, 1993) (unpublished). Ghana's Constitution typically identifies environmental protection as a human right imposing duties on the government and individuals, and refers to protecting "the wider international environment for mankind." S.O. Gyandoh, Constitutional Protection of Human Rights and the Environment Under Ghana's Fourth Republican Constitution, 1992, Address at Commonwealth Institute's Human Rights Approaches to Environmental Protection in the Commonwealth and Beyond Conference, (May 27-28, 1993) (unpublished). Brazil's Constitution, chapter 6 of which solely concerns the environment, guarantees the collective "right to an ecologically balanced environment." CONSTITUIÇÃo FEDERAL [Constitution] art. 225, ch. 6 (Brazil). Ten constitutions in the Asia-Pacific region contain environmental protection provisions. Mizanur Rahman Shelley, Environmental Legislation: Status, Trends and Areas of Concern, Address at Economic and Social Commission for Asia and the Pacific/United Nations Development Program Expert Group Meeting on Institutions, Legislation and Public Participation Relating to the Environment, (Dec. 9-13, 1991); Iveta Hodkova, Is There a Right to a Healthy Environment in the International Legal Order?, 7 CONN. J. INT'L L. 65, 77 (1991); Henry W. McGee \& Kurt Zimmerman, The Deforestation of the Brazilian Amazon: Law, Politics, and International Cooperation, 21 UNIV. MIAMI INTER-AM. L. REV. 513, 531, (1990).

63. See generally G. Heine, Elaboration of Norms and the Protection of the Environment, 2 DUKE ENVTL. L. \& POL'Y 106, 107-08 (1992). Chile's January 25, 1994 environmental legislation, for instance, enshrined in the Constitution the right to live in a pollution-free environment and established a framework of laws, standards and plans to protect it. CHILEAN CONST. ch. III, art. 19(8). 
and such principles as proper valuation of natural resources, ${ }^{64}$ incorporation of environmental costs into economic assessments, ${ }^{65}$ polluter pays, ${ }^{66}$ pollution prevention and precautionary action, ${ }^{67}$ citizen standing to sue ${ }^{68}$ and intergenerational equity. ${ }^{69}$ Many of these provisions are at best symbolic and at worst cynical, particularly in LDCs determined not to allow environmental considerations to impede rapid industrialization. That they exist at all, however, indicates changing attitudes; and increasingly they are being enforced by the courts. Indian courts, for example, have clearly articulated a fundamental right to a healthy environment, significantly on the basis of the Constitution's guaranteed rights to life and liberty. ${ }^{70}$ Courts there and in Argentina, Colombia, Malaysia, and the Philippines have recognized citizen standing to complain of breaches of environmental laws. ${ }^{71}$ In a celebrated class action discussed in Section II(B)(1)(d), the Supreme Court of the Philippines recently threw the validity of all timber licenses in that country into doubt in a decision based on Article II, Section 16 of the Constitution, which guarantees present and future generations "a balanced and healthful ecology" based on the "concepts of intergenerational responsibility and intergenerational justice." "72

\section{Trust}

The notion that humanity holds the earth in trust for God and/or future generations has long influenced both Eastern and aboriginal religions and

64. Federal Act on the Protection of Waters from Pollution (1971) (Switz.).

65. National Environmental Policy Plan (1989) (Neth.). See Hans van Jijst, $A$ Change in Culture, ENVIRON. F., May/June 1993, at 12.

66. Ecocycle Bill (1993) (Swed.).

67. For the European Commission's recommendations for an enforceable code of civil liability for environmental damage, see Communication from the Commission to the Council and Parliament and the Economic and Social Committee: Green Paper on Remedying Environmental Damage, COM (93) 47 final.

68. Brazil's Constitution recognizes a citizen's right to launch "popular actions" to have governmental measures "detrimental to the public estate" declared void. Karen M. Schwab, Added Hope for the Amazon Rain Forest, 15 Houst. J. INT'L L. 163, 190-91 (1992). Nigeria recognizes public rights to enforce its environmental protection laws. A. Ibrahim, The Concept of a Fundamental Right to a Healthy Environment Under Nigerian Law, Address at Human Rights Approaches to Environmental Protection in the Commonwealth and Beyond Conference (May 27-28, 1993) (unpublished).

69. See CONSTITUIÇÃo FEDERAL art. 225 (Brazil). The preamble to Papua New Guinea's Constitution establishes as a national goal the replenishment of the country's natural resources and environment "for the benefit of future generations." PAPUA N.G. CONST. pmbl.

70. Nandan S. Nelivigi et al., The Judiciary and the Environment: Recent Trends and Developments, 23 ENVTL. POL'Y \& L. 102 (1993); B. Desai, Enforcement of Human Right to Environmental Protection: A Role of Public Interest Litigation in India, Address at Human Rights Approaches to Environmental Protection in the Commonwealth and Beyond Conference (May 27-28, 1993) (unpublished).

71. Mossop, supra note 48, at 9-10.

72. Minors Oposa v. Secretary of the Dept. of Environment and Natural Resources (Sup.

Ct. 1993) (Phil.), reprinted in 33 I.L.M. 173 (1994). See infra Section II(B)(1)(d). 
other creatures - an attitude unfortunately permeating human thought ever since $^{73}$ - the notion of a trust can be inferred from the Bible. ${ }^{74}$ The same concept can be seen today in, for example, the preamble to Papua New Guinea's Constitution and the South African bill of rights. ${ }^{75}$ Certain principles-not unrelated to the trust concept, in that they limit private rights in favor of communal interests-were considered part of the "law of nature" by the Romans, and found their way into English common law from the thirteenth century and through Magna Carta. They were then incorporated into U.S. jurisprudence through the Supreme Court decision in Martin v. Waddell. ${ }^{76}$ As the environmental trust concept is philosophically and logically compatible with principles of conservation of biological diversity and ecological integrity, sustainable resource use and waste minimization, proper resource valuation, social equity, community participation, and intergenerational equity, it is not surprising that it is finding acceptance in Western legal systems. The most advanced instance is in the United States, where the "public trust doctrine" means that some natural resource interests are so important that the government is obliged to protect them as trustee for the entire public, as beneficiaries, rather than leaving them subject to private ownership. Any individual has standing to enforce "public rights" under such a trust. ${ }^{77}$

\section{B. International Law}

States and, theoretically, individuals and organizations wilfully, recklessly or negligently causing or permitting environmental harm meeting the

73. See Genesis 1:26; Al-Isrāa 70. For a history of Judeo-Christian "speciesism," see SINGER, supra note 25 , at $192-220$.

74. Leviticus 25:23 ("the land is mine and you are but aliens and tenants"); Leviticus 19:910; 25:3-7; Exodus 23:10-11.

75. S. AFr. CONST. (May 8, 1996) ch. II (Bill of Rights), art. 24 ("Everyone has the right (a) to an environment that is not harmful to their [sic] health or well being; and (b) to have the environment protected, for the benefit of present and future generations, through reasonable legislative and other measures that ... (iii) secure ecologically sustainable development and use of natural resources while promoting justifiable economic and social development.").

76. Martin v. Waddell, 41 U.S. 367 (1842). See Steven W. Turnbull, The Public Trust Doctrine: Accommodating the Public Need Within Constitutional Bounds, 63 WASH. L. REV. 1087,1089 (1988).

77. Joseph L. Sax, The Public Trust Doctrine in Natural Resource Law: Effective Judicial Intervention, 68 MICH. L. REV. 471 (1970); James J. Lawler \& William M. Parle, Expansion of the Public Trust Doctrine in Environmental Law: An Examination of Judicial Policy Making by State Courts, 70 SoCIAL SCIENCE Q. 134, 135 (1989) (describing increasing citizen use of the public trust doctrine in the U.S. to vindicate the public's rights over private lands, and demonstrating that the doctrine, though limited, is rapidly developing); T. Christie, The Law and the Environment, 27 WILDLIFE AUSTRALIA, at 24, 26 (1990) (indicating that the idea of environmental or public trusts is gaining favor at the conceptual level in other Western states, such as Australia). See also The Valdez Principles for Corporate Environmental Behavior, reprinted in Donna Craig, Environmental Law: Corporate Responsibilities and Commercial Transactions, Address at Environmental Outlook Conference (Nov. 10, 1993) (unpublished), at app. II. 
conditions described in Section I(A) breach a duty of care owed to the international community - an obligation erga omnes-and thus commit ecocide under international law. That law arises from the sources enumerated by Article $38(1)$ of the Statute of the $\mathrm{ICJ}^{78}$ - treaties, customary international law, "general principles of law recognized by civilized nations," judicial decisions and "teachings of the most highly qualified publicists"-and develops through the "soft law" of government declarations and the resolutions of international organizations. It is a mixture of international environmental law and human rights law, each of which is evolving towards the other. While exhaustive coverage of this law is beyond the scope of this Article, an examination of key sources and trends will prove the argument.

Within the sphere of international environmental law, there has been parallel development of state responsibility for environmental damage resulting from the breach of international obligations, and state liability to compensate for environmental damage resulting from lawful activities. As ecocide is an international delict based on fault, this analysis is concerned with the former, being codified by the International Law Commission (ILC) in its Draft Articles on State Responsibility, ${ }^{79}$ Article 3 of which provides that "[ $t]$ here is an internationally wrongful act of a State when (a) conduct consisting of an act or omission is attributable to the State under International Law; and (b) that conduct constitutes a breach of an international obligation of the State." The latter, being codified in the ILC's Draft Articles on International Liability for Injurious Consequences Arising Out of Acts Not Prohibited by International $\mathrm{Law}^{80}$ is too narrow and rigorous for this analysis, based as it is on indirectly caused problems like climate change. It will nevertheless become increasingly relevant through regimes establishing strict and absolute liability for dangerous or ultrahazardous activities, including space exploration and nuclear energy production. ${ }^{81}$

78. Statute of the International Court of Justice, June 26, 1945, 59 Stat. 1055 [hereinafter Statute of the ICJ].

79. Report of the Commission to the General Assembly on the work of its thirty-second session, [1980] 2(II) Y.B. Int'l L. Comm'n 30, U.N. Doc. A/CN.4/SER.A/1980/Add.I(Part 2), U.N. Sales No. E.81.V.4 (Part II). See also Report of the Commission to the General Assembly on the work of its thirty-seventh session, [1986] 2(II) Y.B. Int'l Comm. 35, U.N. Doc. A/SER.A/1986/Add.1(Part 2), U.N. Sales No. E.87.V.8 (Part II) (Articles 1-5); Report on the forty-fifth session, supra note 29, at 53-54 (Articles 1-10bis).

80. Report of the Commission to the General Assembly on the work of its forty-first session. [1989] 2(II) Y.B. Int'l L. Comm'n 84-87, U.N. Doc. A/CN.4/SER.A/1989/Add. I(Part 2), U.N. Sales No. E.91.V.5 (Part 2) (Articles 1-17); Report of the Commission to the General Assembly on the work of its forty-second session, [1990] 2(II) Y.B. Int'l L. Comm'n 98-103, U.N. Doc. A/CN.4/SER.A/1990/Add.1, U.N. Sales No. E.92.V.10 (Part 2) (Articles 18-33).

81. E.g., the Convention on International Liability for Damage Caused by Space Objects, Mar. 29, 1972, 961 U.N.T.S 187, 10 I.L.M. 965 [hereinafter Space Objects Convention]. See A. Rosas, Issues of State Liability for Transboundary Environmental Damage, 60 NoRDIC J. INT'L L. 29 (1991); Karl Zemanek, Responsibility of States: General Principles, 10 ENCYCLOPEDIA OF PUB. INT'L L. 362, 363-65 (1987). Riccardo Pisillo-Mazzeschi, Forms of International Responsibility for Environmental Harm, in INTERNATIONAL RESPONSIBILITY FOR ENVIRONMENTAL HARM (Francesco Francioni \& Tullio Scovazzi, eds., 1991); Mohammed Bedjaoui, Responsibility of States: Fault and Strict Liability, 10 ENCYCLOPEDIA OF PUB. INT'L L. 358 


\section{Judicial Decisions}

\section{a. Sovereignty}

State sovereignty has long been circumscribed, as stated in SS Lotus, ${ }^{82}$ by international law. It is, in fact, merely "the residuum of power which [a state] possesses within the confines laid down by international law." international law was slow to recognize obligations concerning the environment, however, sovereignty was long an effective barrier to responsibility for ecocide. States were free to act provided they respected "each other's sovereign equality and individuality as well as all the rights inherent in and encompassed by its sovereignty, including in particular the right of every State to juridical equality, to territorial integrity and to freedom and political independence." 84

That characterization of sovereignty remains valid; but its inherent tension between the rights of the actor and the rights of those states affected-between non-interference in domestic affairs and cooperation with the international community - has increasingly come to be judicially resolved in favor of imposing responsibility. In a shrinking world of shared and limited resources, each state's right not to suffer environmental damage or harm to the health of its people has prevailed over, say, its neighbors' right to exploit their natural resources as they please. This shift does not represent an erosion of sovereignty. It can be seen as a balancing of fundamental rights and duties, or "limited territorial sovereignty," an international law analogue of sic utere,$^{85}$ and is in fact a refinement and strengthening of sovereignty.

\section{b. Duty of Care}

International environmental jurisprudence began with the 1941 Trail Smelter arbitration ${ }^{86}$ concerning damage in the state of Washington caused by sulphur dioxide emissions from a British Columbia smelter. Although it drew upon U.S. Supreme Court decisions concerning interstate pollution, ${ }^{87}$

(1987) (postulating that responsibility and liability will converge as creating liability risks comes to be seen as breaching an international obligation).

82. S.S. Lotus, 1927 P.C.I.J. (Ser. A), No. 10, at 19.

83. STARKE, supra note 21 , at 96.

84. Final Act of the Conference on Security and Co-operation in Europe, Aug. 1, 1975, 14 I.L.M. 1292 [hereinafter Helsinki Final Act].

85. Aaron Schwabach, The Sandoz Spill: The Failure of International Law to Protect the Rhine from Pollution, 16 ECOLOGY L.Q. 443, 457 (1989).

86. Trail Smelter (U.S. v. Can.), reprinted in 35 AM. J. INT'L L. 684 (1941).

87. See Georgia v. Tennessee Copper Co., 206 U.S. 230 (1907); L.B. Sohn, From the Hills of Tennessee to the Forests of Brazil: A Short History of International Environmental Law, in A.B.A., INTERNATIONAL ENVIRONMENTAL LAW: RECENT DEVELOPMENTS AND IMPLICATIONS 2 (1991). 
the ad hoc tribunal created legal history by introducing sic utere and the "good neighbor" rule of Rylands v. Fletcher to international law. The tribunal stated obiter that "under the principles of international law ... no State has the right to use or permit the use of its territory in such a manner as to cause injury by fumes in or to the territory of another or the properties or persons therein, when the case is of serious consequence and the injury is established by clear and convincing evidence." ${ }^{\text {"88 }}$ The tribunal also observed that, "[a] State owes at all times a duty to protect other States against injurious acts by individuals within its jurisdiction. $" 89$

This principle was followed by the ICJ in Corfu Channel, ${ }^{90}$ establishing "every State's obligation not to allow knowingly its territory to be used for acts contrary to the rights of other States," "91 and the tribunal in the Lac Lanoux arbitration, ${ }^{92}$ which determined that states exercising rights must take those of other states into consideration. ${ }^{93}$ This was the beginning of the principle of equity or "solidarity" between states. The dissenting opinion of Judge De Castro in the Nuclear Tests cases ${ }^{94}$ indicates that the Trail principle has remained valid in establishing state responsibility for an internationally wrongful act—breach of the duty not to use or allow the use of national territory in a manner resulting in environmental harm to another state. Both duty and principle are now accepted as customary international law, binding on all states. ${ }^{95}$

Corfu Channel and Lac Lanoux established the relevant standard of responsibility as due diligence, now widely accepted by state practice. The activity itself, for example rain forest clearance, might be lawful, but the state in control must use all possible measures to prevent transboundary environmental damage. Failure to do so, whether injury results or not, constitutes an internationally wrongful act. Resulting "serious injury"-limited by Trail to property loss—entails state responsibility. ${ }^{96}$

88. Id. at 716 .

89. Id. at 713 .

90. Corfu Channel (U.K. v. Alb.), 1949 I.C.J. 3 (Apr. 9).

91. Id. at 22.

92. Lac Lanoux (Fr. v. Spain) 24 I.L.R. 101 (1957).

93. Id. at 138-39.

94. Nuclear Test (Austl. v. Fr.), 1974 I.C.J. 253, 388-89 (Dec. 20).

95. Richard G. Tarasofsky, Legal Protection of the Environment During International Armed Conflict, 24 NETH. Y.B. INT'L L. 17, 67 (1993).

96. There is no generally accepted interpretation of "serious injury" as mentioned in Trail. One publicist writes that, to entail international responsibility, transboundary pollution had to be "considerable, appreciable or substantial or above normal levels of tolerability." Government of Italy, supra note 62 , at 28,29 . Trail's failure to place value on environmental assets such as wildlife, ecosystems and aesthetics could be as much the result of the U.S. tort law the tribunal considered-which has since become more generous in allowing for ecological loss-as it is a reflection of 1940s attitudes. Alan E. Boyle, Nuclear Energy and International Law: An Environmental Perspective, BRIT. Y.B. INT'L L. 257, 276 (1989). 


\section{c. Standing}

Trail's recognition of the rights of neighboring, directly affected states did little to broaden standing beyond the traditional confines expressed in Article 34(1) of the Statute of the ICJ, which permits only states to bring suit, and the South West Africa cases, ${ }^{97}$ in which the ICJ upheld the requirement of direct material interest in rejecting the validity under international law of the doctrine of actio popularis. ${ }^{98}$ The Court in that case did, however, say that a state might have an individual legal interest in an erga omnes obligation. ${ }^{99}$ The Court did not elaborate, save to say that the interest need not be material but humanitarian considerations were insufficient; ${ }^{100}$ but it did prepare the ground for Barcelona Traction, ${ }^{101}$ in which it stated obiter that there exist "obligations of a State towards the international community as a whole ... [ [which by] their very nature are the concern of all States. In view of the importance of the rights involved, all States can be held to have a legal interest in their protection; they are obligations erga omnes."102 Because universal interests are affected, any state has standing to complain on behalf of the international community of a breach irrespective of whether there is direct injury to its nationals or vested interests.

As ecocide is the breach of an obligation owed to all states and, arguably, through human rights law, individuals, the customary international law doctrines of erga omnes and actio popularis, the latter recognized by four dissenting judges in the Nuclear Tests cases, ${ }^{103}$ provide a means of extending standing under the Trail principle to all states, and possibly individuals, and its protection to the global commons, consisting of res communis - those areas not capable of being placed under territorial sovereignty, such as the high seas and outer space-and terra nullius, areas legally susceptible to acquisition by states but not as yet under territorial sovereignty, such as Antarctica.

\section{d. Recent Cases}

Although modern evolution of the Trail principle under international law has primarily been through treaties and "soft law," 104 it is worth considering two municipal cases suggesting that relevant principles have become part of

97. South West Africa (Eth. v. S. Afr; Liber. v. S. Afr.), 1966 I.C.J. 6 (July 18).

98. Id. at 31-33.

99. Id.

100. Id. at 34 .

101. Barcelona Traction (Belg. v. Spain), 1970 I.C.J. 3 (Feb. 5).

102. Id. at 33 .

103. Kathy Leigh, Liability for Damage to the Global Commons, 14 AusTL. Y.B. INT'L L. $129,150-51$ (1992) (providing examples of Permanent Court of International Justice and ICJ support for the doctrine).

104. See infra Sections II(B)(2) \& (3). 
customary international law and "general principles of law recognized by civilized nations." 105

In Minors Oposa v. Secretary of the Department of Environment and Natural Resources, ${ }^{106}$ forty-three minors and the Philippine Ecological Network brought a class action claiming that deforestation was destroying species, soils, water supplies and indigenous habitats, destabilizing local and global climate, and violating the human rights of self-preservation and selfperpetuation. Remitting the case to the trial court for determination on the merits, Davide J. of the Supreme Court of the Philippines, for the majority, held on the bases of "intergenerational responsibility" and "intergenerational justice" that the present generation could and must sue on behalf of itself and future generations. ${ }^{107}$ The plaintiffs had standing because "every generation has a responsibility to the next to preserve [the] rhythm and harmony [of nature] for the full enjoyment of a balanced and healthful ecology."108 Philippine civil and constitutional law, the Court held, creates a right to a balanced and healthful ecology - which the Court implied underlies all other rights including the right to life-and thus imposes on the government an obligation to preserve the environment and a corresponding "duty to refrain from impairing" it. ${ }^{109}$ This decision has since provided a basis for standing in other Philippine NGO suits. ${ }^{110}$

In Dagi v. BHP Minerals Pty Ltd. and Ok Tedi Mining Limited, ${ }^{111}$ 17,000 traditional landowners from Papua New Guinea have brought a class action against an Australian mining company over pollution of the Ok Tedi and Fly rivers. In a writ filed in the Supreme Court of Victoria on May 5, 1994 , the plaintiffs allege that BHP's contamination of water used to provide food, transportation and irrigation, and crucial to the local economy and religious ceremonies, constitutes both private and public nuisance, negligence, and an inherently harmful and dangerous activity entailing strict liability. The action has undergone procedural and political delays, ${ }^{112}$ but the seriousness with which it is being treated by both the Papua New Guinea government at home and an Australian defendant in an Australian court tends to support the

105. Statute of the ICJ, supra note 78, art. 38(1)(c). See RESTATEMENT (THIRD) OF THE FOREIGN RELATIONS LAW OF THE UNITED STATES § 102(1) (1987) (regarding the development of international law "by derivation from general principles common to the major legal systems of the world.").

106. (Sup. Ct. 1993) (Phil.), reprinted in 33 I.L.M. 173.

107. Id. at 176,185 .

108. Id. at 185 .

109. Id. at 188.

110. Ben Boer, Environmental Law in the Pacific Region, Address at Environmental Outlook Conference (Nov. 10, 1993) (unpublished), at 25.

111. Dagi v. BHP Minerals Pty Ltd. and Ok Tedi Mining Limited, No. 5782 (Sup. Ct. 1994) (Vict.) (Austl.).

112. See G. Barker \& B. Pheasant, Court Ruling Delays Ok Tedi Bill, AUSTL. FIN. REV., Sept. 21, 1995, at 3; Rowan Callick, Evans in plea to PNG over Ok Tedi affair, AUSTL. FIN. REV., Feb. 26, 1996, at 3. 
view that sic utere and the rule in Rylands v. Fletcher have become universally accepted legal principles.

\section{Treaties}

The North Sea Continental Shelf cases $^{113}$ establish that a treaty rule constitutes customary international law, binding on parties and non-parties alike, if it declares pre-existing customary international law, crystallizes customary international law which is in the process of formation, or generates new customary international law after adoption. ${ }^{114}$ A treaty rule can arise from a multilateral agreement open to a large number of states if the rule is intended to establish a uniform and binding standard of conduct and is widely accepted. ${ }^{115}$ In all these ways, the approximately nine hundred international environmental legal instruments now in existence facilitate customary international law's extension of the Trail principle. They have increased international influence over both activities within a state's borders and those outside its borders but under its jurisdiction or control, extended coverage beyond transboundary pollution to global environmental harm, and shifted emphasis from states' rights, including sovereignty over natural resources, to community and individual rights. An examination of significant multilateral treaties reveals not only the status, but also the future, of international environmental law.

\section{a. Duty of Care}

While invariably referring to sovereignty over natural resources, major environmental treaties emphasize that sovereignty is limited by international law. The preamble to the U.N. Framework Convention on Climate Change, ${ }^{116}$ for example, declares that "States have, in accordance with the ... principles of international law, the sovereign right to exploit their own resources pursuant to their own environmental and developmental policies." Even the Treaty for Amazonian Cooperation, ${ }^{117}$ which stresses unrestricted sovereignty over the resources of the rain forest, acknowledges those restrictions arising from international law. The restrictions created or evidenced by treaty-aside from special regimes for legal but dangerous or ultrahazardous activities, such as the U.N. Convention on the Prohibition of

113. North Sea Continental Shelf (F.R.G. v. Den.; F.R.G. v. Neth.), 1969 I.C.J. 3 (Feb. 20).

114. Id. at 41.

115. Id.

116. United Nations Framework Convention on Climate Change, May 9, 1992, 31 I.L.M. 849 [hereinafter Climate Change Convention].

117. Treaty for Amazonian Cooperation, July 3, 1978, 1202 U.N.T.S. 71, 17 I.L.M. 1045. 
Military or Any Other Hostile Use of Environmental Modification Techniques ${ }^{118}$ and the Space Objects Convention, ${ }^{119}$ which impose, respectively, strict and absolute liability; and the Paris Convention on Third Party Liability in the Field of Nuclear Energy, ${ }^{120}$ the Vienna Convention on Civil Liability for Nuclear Damage ${ }^{\mathbf{1 2 1}}$ and the International Convention on Civil Liability for Oil Pollution Damage, ${ }^{122}$ which primarily govern the activities of private operators-amount overwhelmingly since the 1972 U.N. Conference on the Human Environment (Stockholm Conference) to a due diligence obligation on states to prevent activities under their jurisdiction or control from causing environmental harm to other states or the global commons. Responsibility arises not from the harm itself but from the failure to exercise due diligence.

An example is Article 194 of the U.N. Convention on the Law of the Sea, ${ }^{123}$ paragraph 2 of which provides that "States shall take all measures necessary to ensure that activities under their jurisdiction or control are so conducted as not to cause damage by pollution to other States and their environment [or] spread beyond the areas where they exercise sovereign rights." Paragraph 1 defines "all measures ... necessary" as "the best practicable means at their disposal and in accordance with their capabilities," and specifically extends the duty of care to "the marine environment." Other treaties extending the duty of care to the global commons are the Vienna Convention for the Protection of the Ozone Layer, ${ }^{124}$ the Treaty on Principles Governing the Activities of States in the Exploration and Use of Outer Space, Including the Moon and Other Celestial Bodies, ${ }^{125}$ the Agreement Governing the Activities of States on the Moon and Other Celestial Bodies $^{126}$ and the Convention for the Regulation of Antarctic Mineral Resource

118. Convention on the Prohibition of Military or any other Hostile Use of Environmental Modification Techniques, G.A. Res. 72, U.N. GAOR, 31st Sess., Supp. No. 39, at 36-28, U.N. Doc. A/31/39 (1976), reprinted in 16 I.L.M. 88 [hereinafter ENMOD].

119. Space Objects Convention, supra note 81.

120. Paris Convention on Third Party Liability in the Field of Nuclear Energy, July 29, 1960, 956 U.N.T.S. 264. 727.

121. Vienna Convention on Civil Liability for Nuclear Damage, May 21, 1963, 2 I.L.M.

122. International Convention on Civil Liability for Oil Pollution Damage, Nov. 29, 1969, 973 U.N.T.S. 3, 9 I.L.M. 45.

123. United Nations Convention on the Law of the Sea, Dec. 10, 1982, 21 I.L.M. 1261 (1982) [hereinafter UNCLOS].

124. Vienna Convention for the Protection of the Ozone Layer, Mar. 22, 1975, 26 I.L.M. 1529 [hereinafter Ozone Layer Convention].

125. Treaty on Principles Governing the Activities of States in the Exploration and Use of Outer Space, Including the Moon and Other Celestial Bodies, Jan. 27, 1967, 610 U.N.T.S. 205, 6 I.L.M. 386 (1967) [hereinafter Outer Space Treaty].

126. Agreement Governing the Activities of States on the Moon and Other Celestial Bodies, Dec. 18, 1979, 18 I.L.M. 1434 [hereinafter Moon Treaty]. 
Activities. ${ }^{127}$ The determination of the international community to broaden the customary international law of Trail to cover modern threats to the global environment manifests itself in innovative approaches such as the application of the Geneva Convention on Long-Range Transboundary Air Pollution ${ }^{128}$ to air pollution "which has adverse effects in the area under the jurisdiction of another State at such distance that it is not generally possible to distinguish the contribution of individual emission sources or groups of sources,"129 and the Convention on Biological Diversity 130 to "processes and activities, regardless of where their effects occur, carried out under [state] jurisdiction or control, within the area of its national jurisdiction or beyond the limits of national jurisdiction." 131

Specific obligations and criteria, as with the judicial decisions examined in the previous section, are difficult to find. The key environmental treaties are "framework conventions," like the Ozone Layer Convention, which leave rules and standards to be elaborated by parties either individually or through protocols and annexes, like the Montreal Protocol on Substances that Deplete the Ozone Layer. ${ }^{132}$ Unfortunately, the ozone example is rare; protocols or annexes to put flesh on the bones of, say, the Climate Change and Biodiversity conventions, while under discussion, are many conferences and political compromises away from realization. States are even reluctant to enforce against others what rules do exist, sometimes for political reasons but often because they themselves could face similar accusations. The dearth of specific obligations, however, is not damaging to the author's argument, based as it is on customary international law and general legal principles which, as shown above, are established by judicial decisions and treaties. Moreover, environmental treaties do declare, crystallize and generate further customary international law and principles.

\section{b. Damage}

Although international responsibility arises from breach of the due diligence standard, it is the resulting harm that makes the act or omission ecocide. While many environmental treaty provisions, like UNCLOS Article

127. Convention on the Regulation of Antarctic Mineral Resource Activities, June 2, 1988, 27 I.L.M. 868 [hereinafter CRAMRA]. See also UNCLOS, supra note 123, arts. 139, 235(1), 263(3), 304; Convention on the Prevention of Marine Pollution by Dumping of Wastes and Other Matter, Dec. 29, 1972, 1046 U.N.T.S. 120, 11 I.L.M. 1291 [hereinafter London Dumping Convention].

128. Geneva Convention on Long-Range Transboundary Air Pollution, Nov. 13, 1979, 18 I.L.M. 1442, 1443.

129. Id. art. 1(b).

130. Convention on Biological Diversity, June 5, 1992, 31 I.L.M. 818, 824 [hereinafter Biodiversity Convention].

131. Id. art. 4(b).

132. Protocol on Substances that Deplete the Ozone Layer, Sept. 16, 1987, 26 I.L.M. 1541 [hereinafter Montreal Protocol]. 
194(2), refer to damaging the "environment" without describing the requisite type and degree of harm, ENMOD bars the hostile use of environmental modification techniques with "widespread, long-lasting or severe effects." 133 "Severe" has been interpreted in this context as "involving serious or significant disruption or harm to human life, natural and economic resources or other assets." 134 This provision therefore extends beyond Trail's narrow protection of property loss to encompass human life and "natural resources." Article 1 of the Space Objects Convention also protects individuals, in addition to property. CRAMRA expands upon the protection of natural resources, indeed the natural environment for its own sake, in defining "damage" as "any impact on the living or non-living components of that environment or those ecosystems, including harm to atmospheric, marine or terrestrial life beyond that which is negligible or which has been assessed and judged to be acceptable." 135 UNCLOS similarly refers to ecosystems, habitats and rare species; ${ }^{136}$ and the Madrid Protocol on Environmental Protection to the Antarctic Treaty ${ }^{137}$ goes further in aiming at protecting "the intrinsic value of Antarctica, including its wilderness and aesthetic values," 138 a concern amplified by the Biodiversity Convention's reference to "the intrinsic value of biological diversity and of the ecological, genetic, social, economic, scientific, educational, cultural, recreational and aesthetic values of biological diversity." 139

A number of recent environmental treaties proclaim dual responsibilities to protect human and preserve environmental health, including the Ozone Layer Convention, ${ }^{140}$ the Montreal Protocol, ${ }^{141}$ the Bamako Convention on the Ban of the Import Into Africa and the Control of Transboundary Movement of Hazardous Wastes Within Africa, ${ }^{142}$ and the Basel Convention on the Control of Transboundary Movements of Hazardous Wastes and Their Disposal, ${ }^{143}$ the preamble to which affirms "that States are responsible for the fulfillment of their international obligations concerning the protection of human health and protection and preservation of the environment, and are liable in accordance with international law." The protection of human and

133. ENMOD, supra note 118 , art. 1(1).

134. Tarasofsky, supra note 95 , at 45 .

135. CRAMRA, supra note 127, art. 1(15).

136. UNCLOS, supra note 123, art 194(5).

137. Madrid Protocol on Environmental Protection to the Antarctic Treaty, Oct. 4, 1991, 30 I.L.M. 1455 [hereinafter Madrid Protocol].

138. Id. art. 3(1).

139. Biodiversity Convention, supra note 130 , pmbl.

140. Ozone Layer Convention, supra note 124, pmbl. \& art. 2(1).

141. Montreal Protocol, supra note 132, pmbl.

142. Bamako Convention on the Ban of the Import into Africa and the Control of Transboundary Movement and Management of Hazardous Waste Within Africa, Jan. 29, 1991, 30 I.L.M. 773 [hereinafter Bamako Convention].

143. Basel Convention on the Control of Transboundary Movements of Hazardous Wastes and their Disposal, Mar. 22, 1989, 28 I.L.M. 657 [hereinafter Basel Convention]. 
preservation of environmental health are, of course, fundamental objects of ESD, the attainment of which is mandated by, for example, the Climate Change Convention, ${ }^{144}$ the Biodiversity Convention ${ }^{145}$ and the International Convention to Combat Desertification in Those Countries Experiencing Serious Drought and/or Desertification, Particularly in Africa. ${ }^{146}$

Gaining particular acceptance is the precautionary principle, an important component of ESD. Appearing in treaties such as the Paris Convention on Prevention of Marine Pollution from Land-Based Sources, ${ }^{147}$ UNCLOS, ${ }^{148}$ the Ozone Layer Convention, ${ }^{149}$ the Montreal Protocol, ${ }^{150}$ the Bamako Convention, ${ }^{151}$ CRAMRA, ${ }^{152}$ the Climate Change Convention ${ }^{153}$ and the Biodiversity Convention, ${ }^{154}$ the precautionary principle can be seen as a counterpart to the customary international law obligation of due diligence which underlies ecocide; both require minimization of the risk of harm.

\section{c. Standing}

The Vienna Convention on the Law of Treaties ${ }^{155}$ provides that any party to a multilateral treaty can complain of a material breach, as it constitutes legal injury to all parties regardless of whether particular injury is suffered, ${ }^{156}$ and acknowledges the existence of peremptory norms creating obligations owed erga omnes, breach of which constitutes legal injury to all states regardless of whether particular injury is suffered. ${ }^{157}$ The former provision is of limited relevance to an analysis of ecocide, as it limits standing in two ways: to parties, which are invariably a subset of the community of nations, each of which is affected; and regarding a material breach, which raises diversionary issues of interpretation and is useless in the characteristic absence of specific and measurable treaty obligations. The acknowledgement, though, of jus cogens ${ }^{158}$-customary international law

144. Climate Change Convention, supra note 116, art. 3(4).

145. Biodiversity Convention, supra note 130 , art. 6 .

146. International Convention to Combat Desertification in Those Countries Experiencing Serious Drought and/or Desertification, Particularly in Africa, June 17, 1994, U.N. Doc. A/AC.241/15/Rev.7 (1994), reprinted in 33 I.L.M. 1328 [hereinafter Desertification Convention].

147. Paris Convention for the Prevention of Marine Pollution from Land-Based Sources,

Feb. 21, 1974, 13 I.L.M. 352.

148. UNCLOS, supra note 123, art 194.

149. Ozone Layer Convention, supra note 124, pmbl.

150. Montreal Protocol, supra note 132, pmbl.

151. Bamako Convention, supra note 142 , art. $4(3)(\mathrm{f})$.

152. CRAMRA, supra note 127 , arts. 2-4.

153. Climate Change Convention, supra note 116, art. 3(3).

154. Biodiversity Convention, supra note 130 , pmbl.

155. Vienna Convention on the Law of Treaties, May 23, 1969, 8 I.L.M. 679.

156. Id. art. $60(2)(\mathrm{a})$.

157. Id. arts. $53 \& 64$.

158. Id. art. 53 . 
rules or principles which are fundamental and inalienable, from which no derogation by treaty is permitted and which can only be overridden by a subsequent and contrary norm of the same character-provides a basis for establishing that all states have standing to complain of ecocide. ${ }^{159}$ There is no authoritative list of rules of jus cogens; but human rights are considered as such. ${ }^{160}$ It is submitted that the environmental treaties mentioned in this section may well transform the customary international law obligation, based on international environmental law and human rights law, to protect states and the global commons from environmental harm into jus cogens.

\section{d. Common Concern of Mankind}

Support for this proposition comes from the ESD principle of the "common concern of mankind," which holds that the international community has a legal interest under international law in the environment of the global commons, and that damage to the global commons is therefore an injurious act against the international community and a breach of the erga omnes obligation to prevent such damage. The principle began with the 1967 proposal by Malta's Ambassador to the U.N. that the mineral resources of the deep seabed beyond the limits of national jurisdiction be declared the "common heritage of mankind," to be shared by and conserved for mankind as a whole. ${ }^{161}$ It gained recognition through a number of U.N. resolutions and Articles 133 to 170 of UNCLOS; however, it is not yet clear that it is sufficiently defined or accepted, particularly by Western states, to constitute customary international law. When, in 1988, Malta further proposed that global climate be declared the common heritage of mankind, opposition to the concept's proprietary element, especially regarding the resources of the deep seabed, led to a political compromise: the "common concern of mankind." Closely related to the doctrines of equitable sharing and public trust, that principle was first recognized in U.N. General Assembly Resolution 43/53 of 1988 on the protection of the global climate for present and future genera-

159. The Draft Articles on State Responsibility provide that states can pursue remedies for breach of treaty or customary international law, regardless of particular injury, where the breach "necessarily affects the enjoyment of the rights or the performance of the obligation of the other States parties to the multilateral treaty or bound by the rule of customary international law." Draft Articles on State Responsibility, art. 5(2)(e)(ii), reprinted in [1993] 2(II) Y.B. Int'l L. Comm'n 54, U.N Doc. AVCN.4/SER.A1993/Add.1(Part 2), U.N. Sales No. E.95.V.4 (Part 2). The Third Restatement provides that "[a] state may bring a claim against another state for a violation of an international obligation owed to the claimant state or to states generally." RESTATEMENT, supra note $105, \S 902$ (1). The Restatement also makes clear that significant injury to the general environment of another state or the global commons constitutes such a violation. Id. $\S \S 601-602$.

160. OsCaR SChachter, International LAW IN THEORY AND PRACTICE 343 (1991).

161. United Nations Convention ON THE LaW OF THE SEa 1982: A COMMENTARY XXvi (Myron H. Nordquist ed., 1985). 
tions of mankind, ${ }^{162}$ and has since become customary international law through implicit recognition by, for example, the Outer Space Treaty, ${ }^{163}$ the Paris Convention Concerning the Protection of the World Cultural and Natural Heritage, ${ }^{164}$ the Convention on International Trade in Endangered Species of Wild Fauna and Flora, ${ }^{165}$ the Moon Treaty ${ }^{166}$ and the Madrid Protocol, ${ }^{167}$ and explicit recognition as the "common concern of humankind" in, for example, the preambles to the Climate Change, Biodiversity and Desertification Conventions.

\section{Declarations and Resolutions}

Though not legally binding, so-called "soft law," consisting primarily of government pronouncements, and declarations and resolutions of international organizations, both serves as evidence and shapes the development of customary international law and "general principles of law recognized by civilized nations." 168 Linking international environmental law with human rights law, soft law manifests the opinio juris - the conviction of acting legally and morally - underlying the customary international law relevant to ecocide. Where it expresses wide consensus as to a rule of international law, soft law is strong evidence of that rule, even in the absence of consistent state practice. At the very least, it indicates normative tendencies and contributes to the formation of international law. ${ }^{169}$ As catalyst and supplement, soft law has been described as "the thin end of the normative wedge of international environmental law, perhaps the 'Trojan Horse of environmentalists." $" 170$

162. G.A. Res. 53, U.N. GAOR, 43d Sess., Supp. No. 49, at 133-34 U.N. Doc. A/43/49 (1988).

163. Outer Space Treaty, supra note 125 , art. 9.

164. Convention for the Protection of the World Cultural and National Heritage, Nov. 16, 1972, 1037 U.N.T.S. 151.

165. Convention on International Trade in Endangered Species of Wild Fauna and Flora, Mar. 3, 1973, 993 U.N.T.S. 243 [hereinafter CITES].

166. Moon Treaty, supra note 126, arts. arts. 1, 3, 7, 11(1).

167. Madrid Protocol, supra note 137, art. 3.

168. Statute of the ICJ, supra note 78, art. 38(1)(c).

169. LOUIS HENKIN ET AL., INTERNATIONAL LAW: CASES AND MATERIALS 114-30 (1980).

170. Günther Handl, Environmental Security and Global Change: The Challenge to International Law, 1 Y.B. INT'L ENVTL. L. 3, 8 (1990). See World Conservation Union Commission on Environmental Law and International Council of Environmental Law, International Covenant on Environment and Development (1995), reprinted in 13 PACE ENVTL. L. REV. 133, 160 (1995). 


\section{a. Principle 21}

If soft law is a Trojan horse, Principle 21 of the Declaration on the Human Environment, ${ }^{171}$ adopted at the Stockholm Conference, is akin to Odysseus: the most effective weapon it contains. It is no exaggeration to say that Principle 21 has revolutionized international environmental law. Not expressed as legally binding, but reflecting significant pre-existing state practice and regarded by many participating states as reflecting international law at the time, Principle 21 was subsequently declared customary international law by General Assembly Resolution 2996 (XXVII) on International Responsibility of States in Regard to the Environment ${ }^{172}$ (with no contrary votes) and is now accepted as such. ${ }^{173}$ Declaring that "States have ... the sovereign right to exploit their own resources pursuant to their own environmental policies, and the responsibility to ensure that activities within their jurisdiction or control do not cause damage to the environment of other States or of areas beyond the limits of national jurisdiction,"174 it extends the Trail principle in a number of important ways. It covers activities conducted not just within national territory, but within state "jurisdiction or control," which would include off-shore corporate operations as well as state participation in the decisions of multilateral development banks, international associations and governmental groupings. It also proscribes "damage to the environment," which goes beyond the traditional emphasis on the effects of pollution on proprietary or economic interests. Most significantly, it explicitly covers damage to the global commons, thus widening the duty of care to cover, for example, the ozone layer, global climate and biological diversity, and affording standing to all states, possibly even individuals. Principle 21 makes the global environment an erga omnes concern.

Its normative character has been recognized and elaborated upon by virtually every multilateral environmental treaty and soft law instrument since 1972. The list of instruments explicitly or implicitly reaffirming Principle 21 includes General Assembly Resolution 2994 (XXVII) endorsing the Stockholm Declaration, ${ }^{175}$ the London Dumping Convention, ${ }^{176}$ General Assembly Resolution 3281 (XXIX) on the Charter of Economic Rights and

171. DECLARATION OF THE UNITEd NATIONS CONFERENCE ON THE HUMAN ENVIRONMENT, U.N. Doc. AVCONF.48/14 \& Corr.1 (1972), reprinted in 11 I.L.M. 1416, 1420 [hereinafter STOCKHOLM DECLARATION].

172. G.A. Res. 2996, U.N. GAOR, 27th Sess., Supp. No. 30, at 42 , U.N. Doc. A/8730 (1972).

173. SCHACHTER, supra note 160 , at 364 .

174. STOCKHOLM DEClARATION, supra note 171, princ. 21. (1972).

175. G.A. Res. 2994, U.N. GAOR, 27th Sess., Supp. No. 30, at 42, U.N. Doc. A/8730

176. London Dumping Convention, supra note 127. 
Duties of States, ${ }^{177}$ the Helsinki Final Act, ${ }^{178}$ the Convention on LongRange Transboundary Air Pollution, ${ }^{179}$ UNCLOS, ${ }^{180}$ the Ozone Layer Convention, ${ }^{181}$ the Climate Change ${ }^{182}$ and Biodiversity ${ }^{183}$ conventions, the Non-Legally Binding Authoritative Statement of Principles for a Global Consensus on the Management, Conservation and Sustainable Development of All Types of Forests, ${ }^{184}$ the Rio Declaration on Environment and Development ${ }^{185}$ (Principle 2 of which is almost identical), and the Desertification Convention, which reaffirms both Principle 21 of the Stockholm Declaration $^{186}$ and Principle 2 of the Rio Declaration. ${ }^{187}$

This seminal influence on international environmental law is, depending upon one's view of international law, either surprising given Principle 21 's lack of precision, or a direct result of the same. ${ }^{188}$ The standard of responsibility it imposes on states is unclear, though generally understood to be due diligence. ${ }^{189}$ The Third Restatement buttresses this interpretation in its description of the environmental responsibilities of states:

A state is obligated to take such measures as may be necessary, to the extent practicable under the circumstances, to ensure that activities within its jurisdiction or control . . . conform to generally accepted international rules and standards for the prevention, reduction and control of injury to the environment of another state or of areas beyond the limits of national jurisdiction .... ${ }^{190}$

The nature and degree of environmental harm constituting a breach are left to other instruments, some employing general terms reminiscent of Trail's "of

177. Charter of Economic Rights and Duties of States, G.A. Res. 3281, U.N. GAOR, 29th Sess., Supp. No. 31, at 50-55, U.N. Doc. A/9631 (1974), reprinted in 14 I.L.M. 251 [hereinafter Charter of Economic Rights and Duties].

178. Helsinki Final Act, supra note 84.

179. Convention on Long-Range Transboundary Air Pollution, supra note 128.

180. UNCLOS, supra note 123.

181. Ozone Layer Convention, supra note 124, at 1529-40.

182. Climate Change Convention, supra note 116.

183. Biodiversity Convention, supra note 130, art. 3.

184. United Nations Conference on Environment and Development, U.N. Doc. A/CONF.151/6/Rev.1, reprinted in 31 I.L.M. 881 (1992) [hereinafter Statement of Forests Principles].

185. Rio Declaration on Environment and Development, June 14, 1992, 31 I.L.M. 874, 876 [hereinafter Rio Declaration].

186. Desertification Convention, supra note 146, art. 3(a).

187. Id. pmbl. See Boyle, supra note 96, at 269; Resolution on Pollution of Rivers and Lakes, arts. 2 \& 5, 58 ANNUAIRE INST. DROIT INT'L 196 (1979).

188. The author sees merit in each view. The consensus necessary for the creation of customary international law could not have been achieved and maintained were Principle 21's prescription more detailed. Standards in this field evolve incrementally. On the other hand, Principle 21's generality could have led to its being ignored, had the international community not been determined, in the ensuing period, to develop international environmental law.

189. Pisillo-Mazzeschi, supra note 81 , at 32.

190. RESTATEMENT, supra note $105, \S 601$ (1)(a) (author's emphasis). 
serious consequence," such as "serious," "substantial" and "significant injury," "191 others supplying considerable detail, for instance "deleterious effects of such a nature as to endanger human health, harm living resources and ecosystems, impair amenities or interfere with other legitimate uses of the environment." 192

\section{b. Sustainable Development}

Perhaps the most fundamental question about Principle 21, though, is whether it is inherently contradictory in proclaiming both state responsibility for external environmental damage and state sovereignty in exploiting resources and determining governing environmental policies. Subsequent soft law indicates that, consistent with judicial and treaty developments outlined above, Principle 21 is now interpreted to limit sovereignty by balancing it with the duty to prevent external environmental harm. ${ }^{193}$ Closely related to this balance and supporting this interpretation is ESD: the integration of environment and development policies. This idea was introduced by the Stockholm Declaration, ${ }^{194}$ labelled "sustainable development" by the World Commission on Environment and Development (WCED), ${ }^{195}$ and mandated as the basis for government, corporate, and organizational decision-making by Agenda $21 .{ }^{196}$ ESD is in the process of becoming customary international law through state adherence to declarations and resolutions of international organizations. ${ }^{197}$ Modern soft law instruments abound with references to such ESD principles as sustainable resource management, ${ }^{198}$ polluter

191. See Anthony Leibler, Deliberate Wartime Environmental Damage: New Challenges for International Law, 23 CAL. W. INT'L L.J. 67, 72 (1992).

192. Council Recommendation on Principles Concerning Transfrontier Pollution, OECD Doc. C(74) 224 (Nov. 14, 1974), reprinted in 14 I.L.M. 242, 243.

193. Resolution on Pollution of Rivers and Lakes, supra note 187, art. 2.

194. STOCKHOLM DECLARATION, supra note 171 , princs. 13 \& 27. (1990).

195. WORLD COMMISSION ON ENVIRONMENT AND DEVELOPMENT, OUR COMMON FUTURE

196. REPORT OF THE UNITED NATIONS CONFERENCE ON ENVIRONMENT AND DEVELOPMENT, at 99, U.N. Doc. A/CONF.151/26 (Vol. 1) (1992).

197. Handl, supra note 170, at 23-27; Ben Boer, Environmental Law After Rio, 1 NEW ZEALAND ENVTL. L. REP. 1, 3 (1994). See Report of the World Commission on Environment and Development, G.A. Res. 187, U.N. GAOR 42nd Sess., Supp. No. 49, at 154, U.N. Doc. A/42/49 (1987) (approving the recommendations of the WCED) [hereinafter Report of the WCED].

198. Commonwealth of Nations, Langkawi Declaration on the Environment, Oct. 29, 1989, reprinted in Selected Legal Materials, 5 AM. U.J. INT'L L. \& POL'Y 589, 590 (1990) [hereinafter Langkawi Declaration]; Statement of Forests Principles, supra note 184, princ. 2(b). 
pays, ${ }^{199}$ the precautionary principle, ${ }^{200}$ intergenerational equity, ${ }^{201}$ and the common concern of mankind. ${ }^{202}$

Soft law instruments promote the expansion of both responsibility and standing under international environmental law beyond states. The Stockholm Declaration refers to the acceptance of responsibility by citizens, communities, enterprises and institutions. ${ }^{203}$ The World Charter for Nature, considered "the rule of ethics in respect of the protection of the human environment and the conservation of natural resources,"204 would impose a duty of compliance on individuals. With respect to standing, the increasingly comprehensive conception of "the environment" reflected in, for example, Principle 2 of the World Charter for Nature and identification-by that document ${ }^{205}$ and the President of the U.N. Security Council ${ }^{206}$ - of ecological deterioration as a threat to international peace and security supports the argument that interests in addition to those of states are harmed by ecocide.

\section{c. Human Rights}

Harm to those interests also violates the customary international law of human rights, built upon the "International Bill of Rights"207 but supplemented, elaborated and-in the case of emerging rights-first enunciated by

199. Council Recommendation on the Application of the Polluter-Pays Principle to Accidental Pollution, OECD Doc. C(89)99 (Final) (July 25, 1989), reprinted in 28 I.L.M. 1320; Rio Declaration, supra note 185, princ. 16; Statement of Forests Principles, supra note 184, princ. 13.

200. World Charter for Nature, G.A. Res. 7, U.N. GAOR, 37th Sess., Supp. No. 51, at 17, 110 \& 11, U.N. Doc. A/Res./37/7 (1982); Nairobi Declaration on the State of the Worldwide Environment, U.N. Environment Programme, 10th Sess., Agenda Item 4, U.N. Doc. UNEP/GC.10/INF.5 (1982) [hereinafter Nairobi Declaration], reprinted in 21 I.L.M. 676; Rio Declaration, supra note 185 , princ. 15.

201. StOCKHOLM DeClARATION, supra note 171 , pmbl. para. 6, princs. $1 \& 2$; Charter of Economic Rights and Duties, supra note 177, art. 30; Nairobi Declaration, supra note 200, para. 10. The Charter on Environmental Rights and Obligations of Individuals, Groups and Organizations (Charter on Environmental Rights and Obligations) bases intergenerational equity on the environmental trust concept that every generation receives a natural and cultural legacy in trust from its ancestors and holds it in trust for its descendants. Charter on Environmental Rights and Obligations, art. 1, reprinted in Action for a Common Future: Report on the Regional Conference at Ministerial Level on the Follow-up to the Report of the World Commission on Environment and Development in the ECE Region, May 8-16, 1990, Bergen, Norway, at 50.

202. Charter of Economic Rights and Duties, supra note 177, art. 30; Declaration of the Hague on the Environment, Mar. 11, 1989, reprinted in 28 I.L.M. 1308 [hereinafter Hague Declaration]; Langkawi Declaration, supra note 198.

203. STOCKHOLM DeClARATION, supra note 171, pmbl. para. 7.

204. Bamako Convention, supra note 142, pmbl; Basel Convention, supra note 143, pmbl.

205. World Charter for Nature, supra note 200, pmbl.

206. Statement to Summit Meeting of Security Council Heads of State, U.N. SCOR, 3046th mtg. at 1, U.N. Doc. S/23500 (1992) (statement by John Major, Prime Minister of the U.K and N. Ire., as President of the Security Council).

207. See infra Section II(B)(4). 
soft law. ${ }^{208}$ International declarations and resolutions thus link international environmental law with human rights law, which indisputably recognizes individual rights erga omnes.

Ecocide can be established simply on the basis of the threat serious environmental damage poses to the fundamental human rights to life and to health. The Stockholm Declaration states that "Both aspects of man's environment, the natural and the man-made, are essential to his well-being and to the enjoyment of basic human rights-even the right to life itself."209 Malta accordingly founded its proposal that global climate be declared the common heritage of mankind on the "fundamental right to life and the need to conserve climate as one of the prerequisites of human life."210 Specifically mentioning global warming and ozone layer depletion, the preamble to the Hague Declaration stresses the connection between survival and environmental stability:

The right to live is a right from which all other rights stem. Guaranteeing this right is the paramount duty of those in charge of all States throughout the world. Today, the very conditions of life on our planet are threatened by the severe attacks to which the earth's atmosphere is subjected. ${ }^{211}$

The preamble to the World Charter for Nature even hints at non-humans' right to life in declaring that "life depends on the uninterrupted functioning of natural systems." Similarly, a number of instruments highlight the dependence of health on the environment. Resolution 23.61 of the World Health Assembly, for example, recommends "the establishment of effective control over the condition of the environment as a source of health and life for present and future generations." 212

The emerging rights to a healthy environment and to development gain support and definition from soft law. No doubt influenced by General Assembly Resolution 2398 (XXIII) on technological change and human rights, ${ }^{213}$ which first acknowledged the linkage between environmental impairment and infringement of human rights, Principle 1 of the Stockholm Declaration proclaims that "Man has the fundamental right to . . . adequate conditions of life in an environment of a quality that permits a life of dignity and well-being." This initial, implicit, formulation of an individual right to a healthy environment was not understood at the time to reflect customary

208. M. Cherif Bassiouni, Human Rights in the Context of Criminal Justice: Identifying International Procedural Protection and Equivalent Protections in National Constitutions, 3 DUKE J. COMP. \& INT'L L. 235, 237 (1993).

209. StOCKHOlm DeClaRATION, supra note 171, pmbl. para. 1.

210. Sohn, supra note 87 , at 23.

211. Hague Declaration, supra note 202.

212. Melissa Thorme, Establishing Environment As a Human Right, 19 DENVER J. INT'L L. \& POL'Y 301, 321 (1991).

213. Problems of the Human Environment, G.A. Res. 2398, U.N. GAOR, 23d Sess., Supp. No. 18, U.N. Doc. A/7218 (1968). 
international law and has not subsequently been endorsed by state practice. ${ }^{214}$ Many soft law instruments have, however, shown that this right is developing ${ }^{215}$ and, according to many observers, now exists under customary international law. ${ }^{216}$ As demonstrated in Section II(A), a growing number of municipal laws and constitutions, and regional declarations, ${ }^{217}$ representing DCs and LDCs in all parts of the world, also show the development of this right. Two examples serve, though, to illustrate the distance the right to a healthy environment must still go toward universal acceptance. Principle 1 of the Rio Declaration, a diluted version of the original propos$\mathrm{al}^{218}$ does not echo the Stockholm Declaration's proclamation of the fundamental right to "an environment of a quality that permits a life of dignity and well-being"; rather, it states merely that humans "are entitled to a healthy and productive life in harmony with nature." Western pressure led to a similar dilution of Commission on Human Rights (CHR) Resolution $1994 / 65$ on human rights and the environment; ${ }^{219}$ Cuban draft language describing the right to a healthy environment as "inalienable"220 became the anodyne observation that "promotion of an environmentally healthy world contributes to the protection of the human right to life and health of everyone."'22!

As discussed above, the right to development, whether individual or collective, has not been fully accepted either. Perhaps because it is related to ESD, though, it seems to generate less controversy as it emerges. First recognized by Article 1(1) of the Declaration on the Right to Development, which considers it the basis for all human rights, the right to development appears in a number of General Assembly resolutions, such as the Charter of

214. Gunther Handl, Human Rights and the Protection of the Environment: A Mildly "Revisionist" View in HUMAN RIGHTS, SUSTAINABLE DEVELOPMENT AND THE ENVIRONMENT 117 (A. Canchado Trindade ed., 1992).

215. E.g., World Charter for Nature, supra note 200; Declaration on the Right to Development, G.A. Res. 128, U.N. GAOR, 41 st Sess., Supp. No. 53, at 186, U.N. Doc. A/41/53 (1986); Report of the WCED, supra note 197, princ. 1 ("All human beings have the fundamental right to an environment adequate for their health and well being."); Resolution on the Need to Ensure a Healthy Environment for the Well-being of Individuals, G.A. Res. 94, U.N. GAOR, 45th Sess., Supp. No. 49A, at 178, U.N. Doc. A/45/49 (1990) ("all individuals are entitled to live in an environment adequate for their health and well-being ..."); Charter on Environmental Rights and Obligations, supra note 201, art. 1 (referring to "the fundamental right to [an] environment adequate for . . . health and well-being."); Draft Universal Declaration on Indigenous Rights, U.N. ESCOR, 8th Sess., art. 16, U.N. Doc. E/CN.4/Sub.2/AC.4 (1990).

216. E.S.C. Res. 41, U.N. ESCOR, 46th Sess., Supp. 2, at 5, U.N. Doc. E/CN.4/Sub.2 (1990); Symonides, supra note 17 , at 26.

217. E.g., Additional Protocol to the American Convention on Human Rights in the Area of Economic, Social and Cultural Rights, Nov. 14, 1988, art. 11, 28 I.L.M. 156.

218. Rolston, supra note 26 , at 261.

219. E.S.C. Res. 65, U.N. ESCOR, 50th Sess., U.N. Doc. E/CN.4/1994/L.11/Add.7 (1994) [hereinafter Resolution on Human Rights and the Environment].

220. U.N. ESCOR, 50th Sess., at 2, U.N. Doc. E/CN.4/1994/L.30 (1994).

221. Resolution on Human Rights and the Environment, supra note 219, pmbl. para. 7. 
Economic Rights and Duties, ${ }^{222}$ and other soft law instruments including the Rio Declaration, ${ }^{223}$ the Statement of Forests Principles, ${ }^{224}$ and the CHR resolution on human rights and the environment, which associates the right to development with ESD. Aboriginal activists are working through the U.N. system to synthesize the right to development and ESD into a right to sustainable development, as at the 1993 World Conference on Human Rights, in Vienna. Significantly, the Vienna Declaration and Programme of Action $^{225}$ adopted at that conference identifies environmental amelioration as an outcome of the right to development: "The right to development should be fulfilled so as to meet equitably the developmental and environmental needs of present and future generations." 226

\section{Human Rights}

Ecocide is the breach of a duty of care owed erga omnes. International environmental law establishes and expounds the duty of care; but it is international human rights law which provides its philosophical and jurisprudential foundation. In particular, human rights promote individual standing to complain of environmental harm where responsibility lies with, or in, another state. A selective examination of the "International Bill of Rights," consisting of the Universal Declaration of Human Rights, ${ }^{227}$ the International Covenant on Civil and Political Rights, ${ }^{228}$ and the International Covenant on Economic, Social and Cultural Rights, ${ }^{229}$ along with the United Nations Charter and various regional human rights instruments, reveals that ecocide violates the customary international law of human rights on several counts. ${ }^{230}$

222. Charter of Economic Rights and Duties, supra note 177, art. 7.

223. Rio Declaration, supra note 185 , princ. 3.

224. Statement of Forests Principles, supra note 184, pmbl. para (a) (recognizing "the right to socio-economic development on a sustainable basis").

225. U.N. ESCOR, 1st Sess., U.N. Doc. E/CN.4/AC.45 (1993) [hereinafter VIENNA DECLARATION].

226. Id. para. $\mathrm{I} / 11$.

227. Universal Declaration of Human Rights, G.A. Res. 217(III), U.N. Doc. A/810, at 71 (1948) [hereinafter Universal Declaration].

228. International Covenant on Civil and Political Rights, Dec. 16, 1966, 999 U.N.T.S. 171, 6 I.L.M. 368 [hereinafter ICCPR].

229. International Covenant on Economic, Social and Cultural Rights, Dec. 16, 1966, 993 U.N.T.S. 3, 6 I.L.M. 360 [hereinafter ICESCR].

230. The Universal Declaration was not intended to be a legally binding instrument. It has come to be considered binding customary international law, possibly jus cogens, along with the Covenants, which are binding treaties. PAUL SIEGHART, THE INTERNATIONAL LAW OF HUMAN RIGHTS 53, 54 (1983). 


\section{a. Life}

The right to life-guaranteed by the Universal Declaration, ${ }^{231}$ the ICCPR, ${ }^{232}$ the European Convention ${ }^{233}$ and the American Declaration on the Rights and Duties of $\mathrm{Man}^{234}$-is jus cogens. ${ }^{235}$ Although its context, in particular its frequent conjunction with security of the person, suggests it protects mere physical existence through restrictions on, for instance, arbitrary arrest and detention and the death penalty, its fundamental quality means "the scope of the right to life is evolving to include the quality of life, including the right to food, medical care, education, and a pure and liveable environment." ${ }^{236}$ This evolution imposes on states affirmative duties to protect life by ensuring a healthy environment and the continued coexistence of people and that environment. It is submitted that, at least with respect to refraining from positive acts of ecocide, the duty of states to respect the right to life extends beyond their own borders and citizens.

The Human Rights Committee has warned against interpreting ICCPR Article 6 narrowly. ${ }^{237}$ Article 4 of the African Charter and Article 4(1) of the American Convention on Human Rights, ${ }^{238}$ which proclaim the right to have one's life respected, also invite an expansive interpretation of the right to life. International tribunals such as the European Court of Human Rights (ECHR) and the Inter-American Court of Human Rights (IACHR) have accepted the invitation. ${ }^{239}$ The right to a healthy environment, in fact, was proposed in the 1970s for integration as a specification of the right to life in the European Convention, which established the ECHR. ${ }^{240}$ The IACHR decided in Velasquez Rodriguez ${ }^{241}$ that state duties under the American Convention include "all those means of a legal, political, administrative and cultural nature that promote the protection of human rights." ${ }^{242}$ In

231. Universal Declaration, supra note 227, art. 3.

232. ICCPR, supra note 228, art. 6(1).

233. European Convention, supra note 33, arts. 2(1) \& 5(1).

234. O.A.S. Res. XXX, art. 1, 9th Int'l Conf., Mar. 30-May 2, 1948, Bogota, O.A.S. Off. Rec. OEA/SER.L/V/1.4 Rev (1965).

235. Nagendra Singh, Right to Environment and Sustainable Development as a Principle of International Law, 29 J. INDIAN LAW INST. 289, $289-90$ (1987).

236. Gormley, supra note 16, at 111 (author's emphasis).

237. Gudmundur Alfredsson \& Alexander Ovsiouk, Human Rights and the Environment, 60 NORDIC J. INT'L L. 18, 22-23 (1991).

238. American Convention on Human Rights, Nov. 22, 1969, O.A.S.T.S. No. 36, O.A.S. Off. Rec. OEA/Ser.K/XVI/1.1 doc. 65, Rev. 1, Corr. 2 (1970), reprinted in 9 I.L.M. 673 [hereinafter American Convention].

239. See Michael L. Schwartz, International Legal Protection for Victims of Environmental Abuse, 18 YALE J. INT'L L. 355, 362-63 (1993).

240. Government of Italy, supra note 62 , at 89.

241. Velasquez-Rodriguez Case (Govt. of Honduras), Judgment of July 29 , 1988, Inter-Am.

Ct. H.R., Ser. C: Decisions and Judgments, No. 4, reprinted in 28 I.L.M. 291 (1989).

242. Id. para 175 . 
Yanomami, ${ }^{243}$ the Inter-American Commission of Human Rights determined that, because environmental degradation in the Amazon rain forest can violate the right to life, the Brazilian government, in approving development there, violated that right and rights to health, liberty, personal security, residence and freedom of movement.

\section{b. Development}

The right to the "highest attainable standard of physical and mental health," proclaimed by Article 12(1) of the ICESCR and, with similar wording, Article 5(1) of the American Convention and Article 16(1) of the African Charter, and such associated rights as a standard of living adequate for health and well-being, ${ }^{244}$ social security, ${ }^{245}$ satisfactory conditions of work, ${ }^{246}$ and the realization of economic, social and cultural rights in general, ${ }^{247}$ together amount to an implicit right to development. ${ }^{248}$ That right, though, is explicitly proclaimed only in Article 22 of the African Charter. As a matter of customary international law, it remains aspirational, the obligations qualified, progressive and possibly collective, unlike the absolute and immediate obligations to respect and ensure civil and political rights. ${ }^{249}$ As it takes shape, it will become connected to protection of the local and global environments upon which all rights, especially economic, social and cultural, depend. Growing acceptance of the connection can be seen in paragraph $\mathrm{L} / 11$ of the Vienna Declaration, the criticism that the European Social Charter ${ }^{250}$ recognizes the right to health but not to a healthy environment, ${ }^{251}$ the trend in international human rights jurisprudence to treat environmental responsibility as a governmental obligation to protect human rights, ${ }^{252}$ and municipal court decisions rejecting qualitative or aesthetic grounds for public action against environmental damage but sanctioning such action on grounds of the threat posed to public health and physical well-being. ${ }^{253}$ Even the right of "peoples" to enjoy and dispose of

243. Status of the Yanomami Indians, Case 7615, Inter-Am. C.H.R. 24, OEA/Ser.L/V/II.66, doc. 10, rev. 1 (1985) (Annual Report 1984-1985).

244. Universal Declaration, supra note 227, art. 25; ICESCR, supra note 229, art. 11(1).

245. Universal Declaration, supra note 227, art. 22; ICESCR, supra note 229, art. 9.

246. ICESCR, supra note 229, art. 7.

247. Universal Declaration, supra note 227, art. 22.

248. See also U.N. CHARTER art. 55. Article 55 refers to standards of living, health, "conditions of economic and social progress and development," and human rights. It is unclear whether Article 55, in listing these conditions, links them together or distinguishes them, particularly human rights.

249. ICCPR, supra note 228, art. 2; ICESCR, supra note 229, art. 2.

250. European Social Charter, Oct. 18, 1961, 529 U.N.T.S. 89.

251. See Thorme, supra note 212 , at 321-22.

252. Schwartz, supra note 239 , at 359.

253. Thorme, supra note 212 , at 321. 
their natural wealth and resources ${ }^{254}$ could, with changing social attitudes, eventually be interpreted to prohibit environmental degradation, where it deprives them of their "own means of subsistence," for example through destruction of biological diversity.

\section{c. Environment}

The emerging erga omnes right to a healthy environment ${ }^{255}$ not only forms the necessary foundation for the full realization of all other human rights-quite simply because they would become meaningless to a community unable to breathe, drink, produce food, clothing and shelter, and otherwise care for itself -it represents their logical synthesis. A major object of individual civil and political liberties and programs of community economic, social and cultural advancement is that people might live together peacefully and in dignity in a safe and adequate environment. Article 24 of the African Charter, which proclaims "All peoples shall have the right to a generally satisfactory environment favorable to their development," signifies this synthesis, as "development" aims at the same object. The right to a healthy environment is in effect an extension of the right to development.

\section{d. Standing}

Universally accepted human rights, particularly to life, health, and an adequate standard of living but also, inter alia, to satisfactory conditions of work, culture, and personal liberty, then, support the emergence of the right to a healthy environment and the conclusion "that states have a fundamental duty to refrain from environmentally destructive acts which could injure human beings ... and to take affirmative action to prevent environmental harm where possible."256 This duty, complementary to that arising from Trail and Principle 21 under international environmental law, is one of customary international human rights law, obligations under which are erga omnes. ${ }^{257}$ All states, accordingly, have standing to complain of violations regardless of particular injury. ${ }^{258}$ Ecocide, of course, affects citizens of all states, so a state could always demonstrate that its citizens suffered injury, even if not of the same degree as suffered elsewhere. With increased acceptance of the proposition that ecocide violates the fundamental right to life, and of the right to a healthy environment as jus cogens, states-and possibly international organizations and NGOs-will acquire standing to

254. ICCPR, supra note 228, arts. 1(2) \& 47; ICESCR, supra note 229, arts. 1(2) and 25.

255. Dinah Shelton, Human Rights, Environmental Rights, and the Right to Environment, 28 STAN. J. INT'L L. 103, 105-07 (1991).

256. Schwartz, supra note 239 , at 359-60.

257. See RESTATEMENT, supra note $105, \S 601$ (environmental protection is a customary law obligation).

258. See Draft Articles on State Responsibility, supra note 79, art. 5(2). 
complain on behalf of people generally. As stated in Article 4 of the Vienna Declaration, the "protection of all human rights is a legitimate concern of the international community."

But the ultimate task for international law, in the author's opinion, must be to recognize individual standing. The customary international human rights law basis for ecocide provides individuals with their strongest claim, as human rights is the field in which the customary international law state monopoly on standing is undergoing the greatest erosion. From the humanitarian intervention theories of Gentili ("in the violation of [human rights] law we are all injured") and Grotius, ${ }^{259}$ to procedural rights granted under the Optional Protocol to the ICCPR and the European Convention, international human rights law has long recognized individual interests as distinct from state interests.

International human rights law could also provide standing to the unborn. Intergenerational equity and the environmental trust concept are, at the international level, still mere principles. Brown Weiss argues that they constitute an emerging norm of customary international law imposing on humanity an erga omnes duty as trustee for succeeding generations to preserve global environmental diversity and quality. The norm is based on principles of equity and the common heritage of mankind, and on the human and beneficial rights - probably collective - of the unborn. ${ }^{260}$

\section{International Criminal Law}

It has been demonstrated above that states, and possibly individuals and organizations, wilfully, recklessly or negligently causing or permitting environmental harm as specified in Section I(A) breach an erga omnes duty of care arising from international environmental law and human rights obligations and so commit an international delict. The author calls this delict "ecocide"261 because it literally means "the killing of ecology."262 Such senseless destruction of life and the prospects for entire species strikes the author as more serious than delictual; as his choice of name implies, he considers it criminal. Just as one act or omission can constitute both a tort and a crime under Anglo-American law, one act or omission can constitute both an international delict and an international crime. ${ }^{263}$ It is submitted,

259. Theodore Meron, Common Rights of Mankind in Gentili, Grotius and Suárez, 85 AM. J. INT'L L. 110, 110-15 (1991).

260. Edith Brown Weiss, Our Rights and Obligations to Future Generations for the Environment, 84 AM. J. INT'L L. 198 (1990). See also Anthony D'Amato, Agora: What Obligation does our Generation Owe to the Next? An Approach to Global Environmental Responsibility, 84 AM. J. INT'L L. 190 (1990).

261. A name suggested to him by His Excellency Judge C.G. Weeramantry of the ICJ.

262. The Oxford English Dictionary defines ecology as that "branch of biology which deals with the relations of living organisms to their surroundings." SHORTER OXFORD ENGLISH DICTIONARY 628 (3d ed. 1973).

263. C.G. WEERAMANTRY, NUClEAR WEAPONS AND SCIENTIFIC RESPONSIBILITY 97 (1987). 
not that ecocide is recognized as an international crime per se, but that it possesses the requisite character and therefore could be.

\section{Crime}

A crime is more than a serious tort. According to Glanville-Williams, "the average crime is more shocking, and has graver social consequences, than the average tort."264 A crime is a public wrong, an act or omission deemed harmful to the interests, not just of the immediate victim, but of the entire community. Because it threatens fundamental social values (in Western society, typically civil rights to life, personal security, liberty, peace and order, and protection of property) crime in effect breaches a duty of care owed to everyone. Compliance with the duty of care is the community's concern, so it forbids the act or omission and punishes perpetrators.

Jurists, considering crime from a legal process perspective, define it as conduct forbidden by law, for which the government can inflict punishment. Sociologists emphasize the antisocial nature of the act, its relationship to behavior harmful to society as a whole. Both, though, identify an element of moral outrage on the part of the community against criminals because they have done something "wrong": they have violated the rules and norms of society. As Lord Simonds stated in Shaw v. DPP, ${ }^{265}$ the purpose of criminal law is "to conserve not only the safety and order but also the moral welfare of the state." 266 Crime is therefore that which a society condemns, and criminal law a codification of moral imperatives. ${ }^{267}$

Obviously, which acts and omissions are labelled crimes depends upon a particular society's values. Under Anglo-American law, elements include an act or omission-the actus reus - constituting a violation of prescribed law for which punishment is provided, and intent or criminal negligence-mens rea-the criminal equivalent of fault and the expression of the moral aspect of crime. If a moral choice was possible, the criminal act or omission is deemed deliberate and malicious. There is, however, an increasing number of statutory offenses of strict or absolute liability requiring no mens rea. ${ }^{268}$ As well, the guilt of an officer or employee can be attributed to his company. ${ }^{269}$

264. Geof Gilbert, The Criminal Responsibility of States, 39 INT'L \& COMP. L.Q. 345, 347 (1990) (author's emphasis).

265. Shaw v. DDP, 2 All E.R. 446 (1961), A.C. 220 (H.L. 1962) (U.K.).

266. Id. at 452.

267. Harry E. Allen et al., Crime and Punishment: An Introduction to CrimINOLOGY 4-8, 14-15 (1981).

268. J.C. SMITH \& BRIAN HOGAN, CRIMINAL LAW 87-91 (5th ed. 1983).

269. See Goode, supra note 50, at 103-108. 


\section{International Crime}

\section{a. Crimes Against Humanity}

The foundations of customary international criminal law, the Agreement for the Prosecution and Punishment of the Major War Criminals of the European Axis and Charter of the International Military Tribunal, ${ }^{270}$ and the Judgment of the Nürnberg International Military Tribunal, ${ }^{271}$ are expressions of the moral outrage of the international community as represented by the victorious Allies after World War II. The Nürnberg Charter assigns individual responsibility for three categories of international crime: crimes against peace, war crimes, and crimes against humanity. ${ }^{272}$ It defines the last as "inhumane acts committed against any civilian population" in wartime. ${ }^{273}$ The Nürnberg Judgment states "That international law imposes duties and liabilities upon individuals as well as upon States has long been recognized . . . Crimes against international law are committed by men, not by abstract entities. . . ."274 It lists specific crimes against humanity, committed in execution of, or in connection with, war, crimes against peace, or war crimes. The so-called Nürnberg Principles, ${ }^{275}$ including individual responsibility for international crimes ${ }^{276}$ and recognition of crimes against humanity as "crimes under international law," 277 constitute customary international law. ${ }^{278}$

Crimes against humanity are "organized, deliberately planned and systematic crimes, carried into effect on a wholesale scale"279 and as a matter of government policy. They are violations of jus cogens obligations, which in turn, as stated by the ICJ in Barcelona Traction, ${ }^{280}$ "derive . . .

270. Agreement for the Prosecution and Punishment of the Major War Criminals of the European Axis and Charter of the International Military Tribunal [hereinafter Nürnberg Charter], Aug. 8, 1945, 82 U.N.T.S. 279.

271. International Military Tribunal (Nuremberg), Judgment and Sentences, 41 AM. J. INT'L L. 172 (1946) [hereinafter Nürnberg Judgment].

272. Nürnberg Charter, supra note 270, art. 6.

273. Id.

274. Nürnberg Judgment, supra note 271, at 220-21.

275. Principles of International Law Recognized in the Charter of the Nürnberg Tribunal and in the Judgment of the Tribunal, reprinted in [1950] 2 Y.B. Int'l L. Comm'n 374-78, U.N. Doc. A/CN.4/SER.A/1950/Add.1, U.N. Sales No. 1957.V.3, Vol. II.

276. $I d$. princ. 1 .

277. Id. princ. 6 .

278. See also Affirmation of the Principles of International Law Recognized by the Charter of the Nürnberg Tribunal, G.A. Res. 95(I), U.N. Doc. A/64/Add.1, at 188 (1946). Convention on the Non-Applicability of Statutory Limitations to War Crimes and Crimes Against Humanity, Dec. $16,1968,8$ I.L.M. 68.

279. Joseph B. KeEnan \& Brendan F. Brown, Crimes Against International law 116-18 (1983).

280. 1970 I.C.J. 3 (Feb. 5). 
from the principles and rules concerning the basic rights of the human person." ${ }^{281}$ It is the essential importance of human rights to the international community, rights forming part of the "general principles of international law recognized by civilized nations," that makes aggression, population deportation, slavery, and racial and religious persecution, to name key examples, international crimes.

Domestic penal law ... and the laws of humanity are all the result of the aim of society, whether it be national or international, to make law an instrument for the maintenance of human values, and for their protection against unjust onslaught .... Just as domestic penal law protects vital, basic interests of men living in the society of the State, so the international law of humanity ... a afford[s] a similar protection on an international plane. ${ }^{282}$

This link between human rights and crimes against humanity is evident in a number of treaties. The Convention on the Prevention and Punishment of the Crime of Genocide, ${ }^{283}$ considered customary international law, ${ }^{284}$ confirms General Assembly Resolution 96(1) of 1946, ${ }^{285}$ which states that genocide is a "crime under international law,"286 recommends international cooperation, ${ }^{287}$ and identifies as potential perpetrators individuals "whether private . . public officials or statesmen." ${ }^{, 28}$ The International Convention on the Suppression and Punishment of the Crime of Apartheid ${ }^{289}$ also began with a General Assembly resolution, which reaffirms apartheid as a crime against humanity. ${ }^{290}$ It declares that acts resulting from apartheid's policies and practices are "crimes violating the principles of international law, in particular the purposes and principles of the Charter of the United $\mathrm{Na}$ tions" ${ }^{291}$ and, interestingly, identifies as potential perpetrators individuals, organizations and institutions. ${ }^{292} \mathrm{~A}$ regional treaty, the Inter-American

281. Id. at 33 .

282. KEENAN \& BROWN, supra note 279 , at 114.

283. Convention on the Prevention and Punishment of the Crime of Genocide, Dec. 9, 1948, 78 U.N.T.S. 277 [hereinafter Genocide Convention]. See also Uniting for Peace, U.N. GAOR, 5th Sess., 302 plen. mtg., Doc. A/1481 (1950), reprinted in 45 AM. J. INT'L L. SUPP. 1, 6 (1951).

284. D.J. HARRIS, CASES AND MATERIALS ON INTERNATIONAL LAW 697 (4th ed. 1991).

285. G.A. Res. 96(I), U.N. Doc. A/64/Add.1, at 188 (1946).

286. Id. para. 1 .

287. Id. para. 3 .

288. Id. para. 1 .

289. Convention on the Suppression and Punishment of the Crime of Apartheid, Dec. 6, 1973, U.N. GAOR, 28th Sess., Agenda item 53, U.N. Doc. A/9233/Add.1, A/L.712/Rev.1 (1973), reprinted in 13 I.L.M. 150 [hereinafter Apartheid Convention]. This treaty enjoys little Western support. BROWNLIE, supra note 196, at 162.

290. Elimination of all forms of racial discrimination, G.A. Res. 2784, U.N. GAOR, 26th Sess., Supp. No. 29, at 79-80, U.N. Doc. A/8429 (1971).

291. Id. art. 1(1).

292. Id. art. 1(2). 
Convention to Prevent and Punish Torture, ${ }^{293}$ describes torture as "an offense against human dignity" 294 and applies to individuals. ${ }^{295}$

The analogy between municipal crimes and crimes against humanity extends beyond protection of human rights to the maintenance of social stability. Just as the former threaten public safety and order, the latter can cause individual tensions and thus endanger international peace and security. This is recognized by the Apartheid Convention in both the preamble and Article 1(1).

\section{b. Crimes Against Peace and Security}

The ILC's Draft Code of Crimes Against the Peace and Security of Mankind began as the formulation of the Nürnberg Principles into a Draft Code of Offenses Against the Peace and Security of Mankind. ${ }^{296}$ Although up to 1985 the ILC considered application to states, ${ }^{297}$ and its current draft is without prejudice to future application to states and does not relieve them of "responsibility under international law" for their acts and omissions, ${ }^{298}$ the Code covers only individual responsibility of actors and responsible superiors. ${ }^{299}$ It names such crimes as aggression, ${ }^{300}$ genocide, ${ }^{301}$ apartheid, ${ }^{302}$ and exceptionally serious war crimes, ${ }^{303}$ as well as a list of "sys519.

293. Inter-American Convention to Prevent and Punish Torture, Dec. 9, 1985, 25 I.L.M.

294. Id. pmbl.

295. Id. art. 3.

296. Documents of the second session including the report of the Commission to the General Assembly, [1950] 2 Y.B. Int'l L. Comm'n 249, U.N. Doc. A/CN.4/SER.A/1950/Add.1, U.N. Sales No. 1957.V.3, Vol. II; Documents of the third session including the report of the Commission to the General Assembly, [1951] 2 Y.B. Int'l L. Comm'n 43, U.N. Doc. A/CN.4/SER.A/1951/Add.1, U.N. Sales No. 1957.V.6, Vol. II; Report of the Commission to the General Assembly on the work of its thirty-eighth session, [1986] 2 (II) Y.B. Int'l L. Comm'n 40, U.N. Doc. A/CN.4/SER.A/1986/Add. 1(Part 2), U.N. Sales No. E.87.V.8 (Part II) [hereinafter Draft Code of Offenses]. The Code was mandated by the General Assembly in its resolution on the formulation of the principles recognized in the Charter of the Nürnberg Tribunal and the Judgment of the Tribunal. G.A. Res. 177(II), U.N. Doc. A/519, at 111 (1947). The Code has been elaborated by the ILC since 1978. See G.A. Res. 97, U.N. GAOR, 33d Sess., Supp. No. 45, at 220, U.N. Doc. A/33/45 (1978). In 1987, the General Assembly endorsed the ILC's recommendation that the English title of the Draft Code be changed from Offenses to Crimes Against the Peace and Security of Mankind. G.A. Res. 151, U.N. GAOR, 42d Sess., Supp. No. 49, at 292, U.N. Doc. A/42/49 (1987).

297. See HENKIN ET AL., supra note 169, at 367-68.

298. Draft Code of Crimes Against the Peace and Security of Mankind, art. 5 [1991] 2(II) Y.B. Int'1 L. Comm'n 94-97, U.N. Doc. A/CN.4/Ser.A/1991/Add.1(Part 2), U.N. Sales No. E.93.V.9(Part 2) [hereinafter Draft Code of Crimes].

299. Id. arts. $3(1) \& 12$.

300. Id. art. 15 .

301. Id. art. 19.

302. Id. art. 20.

303. Id. art. 22. 
tematic or mass violations of human rights"304 which largely coincide with the Nürnberg Charter's crimes against humanity, except in that the Code does not explicitly limit such crimes to those committed in execution of or in connection with crimes against peace or war crimes.

The Code also identifies for the first time as an international crime "wilful and severe damage to the environment." 305 Perpetrators are individuals who wilfully cause or order "widespread, long-term and severe damage to the natural environment." 306 It is unclear whether this provision applies in peacetime. Modelled on Article 55(1) of the first additional protocol to the 1949 Geneva Conventions regarding armed conflict, and part of a code based on the Nürnberg Principles, the provision could be intended to cover only war-related acts, such as the igniting of Kuwaiti oil wells during the Gulf War. On the other hand, Article 22(2)(d) identifies environmental warfare as a separate war crime. Either way, Article 26 assists the recognition of ecocide as an international crime as it makes the environment a subject of international criminal law; is based on damage which is serious; ${ }^{307}$ and equates, through juxtaposition in the Code, this kind of environmental damage and recognized international crimes such as those mentioned in the preceding paragraph, particularly "systematic or mass violations of human rights." It goes further than this author proposes in establishing individual guilt. ${ }^{308}$

\section{c. Characteristics}

The Draft Code of Crimes Against the Peace and Security of Mankind is not intended to be exhaustive. The ad hoc development of international criminal law continues without settling what constitutes an international crime and whether it is anything more than a serious international delict: breach of a fundamental erga omnes obligation. Some think not. Tunkin writes "When aggressive war and certain other violations of international law are called

304. Id. art. 21.

305. Id. art. 26.

306. Id.

307. See supra Section $I(A)(1)(a)$. Severity relates to the nature of the damage, its effects, or the motive for commission. TIMOTHY MCCORMACK \& GERRY SIMPSON, THE DRAFT CODE OF CRIMES AGAINST THE PEACE AND SECURITY OF MANKIND: AN ANAL YSIS OF THE RELATIONSHIP BETWEEN THE DRAFT CODE'S SPECIFIC CRIMES AND EXISTING INTERNATIONAL LAW (1993).

308. The ILC's decision in 1995 to focus on the crimes of aggression and genocide, war crimes and crimes against humanity throws the immediate future of Article 26 into doubt. Although the Special Rapporteur dropped six crimes, including "wilful and severe damage to the environment," from the twelve included in the Code on first reading, in response to opposition and reservations, he noted that too few views had been expressed for a final decision to be made. A number of governments had also pointed out that the Code is not intended to cover all international crimes, so that exclusion of one did not mean it does not exist. Report of the Commission to the General Assembly on the work of its forty-seventh session, U.N. GAOR, 50th Sess., Supp. No. 10, U.N. Doc. A/50/10 (1995) [hereinafter Report on the forty-seventh session]. At its forty-eighth session in 1996, the ILC established a Working Group which proposed inclusion of "willful and severe damage to the environment" in Article 22(2) as a war crime. An ILC drafting committee is working on the proposal. 
crimes, one only wishes to emphasize thereby . . . the especially dangerous character of the delinquency . . . the question becomes purely terminological." 309 Referring to Article 19 of part I of the Draft Articles on State Responsibility, ${ }^{310}$ Mohr writes "The term 'international crimes' is only and simply used for labelling a certain kind of internationally wrongful acts [sic] of an extremely grave nature." ${ }^{11}$ This question is obviously relevant to whether ecocide is more than a serious international delict.

Article 19 , supporting the proposition that states can be responsible for international crimes, first distinguished international crimes from international delicts. It identifies an act of state constituting breach of an international obligation as "an internationally wrongful act." ${ }^{12}$ Where such an act "results from the breach by a State of an international obligation so essential for the protection of fundamental interests of the international community that its breach is recognized as a crime by that community as a whole, [it] constitutes an international crime." ${ }^{.313}$ Though somewhat circular, this definition of international crime incorporates the notion of erga omnes obligations and, impliedly, jus cogens. Examples include a serious breach "of an international obligation of essential importance for the maintenance of international peace and security";,314 "on a widespread scale of an international obligation of essential importance for safeguarding the human being"; 315 and "of an international obligation of essential importance for the safeguarding and preservation of the human environment, such as those prohibiting massive pollution of the atmosphere or of the seas."316 "Any internationally wrongful act which is not an international crime in accordance with paragraph 2 constitutes an international delict." ${ }^{\prime 317}$

How serious must the delict be to qualify as a crime? One publicist writes "International crimes, if they exist at all, are the result of the international community [sic] agreeing on and recognizing norms, from which members cannot derogate, which are substantially more serious than jus cogens. ${ }^{318}$ The ILC, reporting on its 46th session in 1994, did not go that far; it described international crimes as extremely serious violations of $j u s$

309. Gilbert, supra note 264 , at 368.

310. For the text of Article 19, see Report of the Commission to the General Assembly on the work of its twenty-eighth session, [1976] 2(II) Y.B. Int'l L. Comm'n 95-96, U.N. Doc. A/CN.4/SER.A/1976/Add.1(Part 2), U.N. Sales No. E.77.V.5 (Part II) [hereinafter Article 19]. Article 19 and the concept of state crime are controversial even within the ILC. Report on the forty-seventh session, supra note 308 , at 135.

311. Gilbert, supra note 264 ; at 368.

312. Article 19 , supra note $310, \$ 1$.

313. Id. \ 2.

314. Id. \3(a).

315. Id. ๆ 3(c).

316. Id. I 3(d).

317. Id. $₫ 4$.

318. Gilbert, supra note 264 , at 350. 
cogens. ${ }^{319}$ It did make clear, though, that international crimes are more than delicts-basic infringements of international public order. They threaten the fundamental premise of international society: peaceful coexistence of sovereign states. ${ }^{320}$ They are human rights violations "on a scale large enough to bestir the conscience of humanity"321 and thus, as General Assembly resolutions naming international crimes indicate, threaten international peace and security.

Bassiouni writes that international crimes display one or more of the following characteristics. They threaten peace and security or, as "conduct recognized as shocking to the conscience of the world community," are contrary to its shared values. ${ }^{322}$ They are transnational in that they affect public interests in more than one state, involve citizens of more than one state, or involve the crossing of borders. ${ }^{323}$ International cooperation is necessary for their prevention, suppression and control. ${ }^{324}$ In his view, there must be intent, knowledge or recklessness; negligence is insufficient. $^{325}$

It is because of mens rea that international criminal law has diverged from the classical international law rule of state responsibility. As demonstrated by the Nürnberg Judgment, international crime has traditionally emphasized the individual. States might have been held responsible to pay penalties or make reparation; but they were not perceived as having the mens rea necessary for criminal accountability. ${ }^{326}$ As the ILC recognized at its 46th session, "collective punishment" of an entire nation also violates the basic criminal law principle against punishing non-actors. ${ }^{327}$ State responsibility for violation of jus cogens, however, is well established; why should a state not be responsible for a serious violation of jus cogens deemed an international crime? International crimes often have a political motivation, and they usually involve government activity, as the Nürnberg Judgment acknowledges.

The Draft Code of Crimes Against the Peace and Security of Mankind and the Draft Articles on State Responsibility together can be seen as maintaining, if somewhat schizophrenically, that both states and individuals can be criminally culpable under international law-perhaps, where an

319. Report on the forty-sixth session, supra note 29 , at 66-67.

320. Id. at 330.

321. Li, supra note 29 , at 111 . The ILC distinguishes the concept of crime under the Draft Code of Crimes Against the Peace and Security of Mankind from that under the Draft Articles on State Responsibility: Report of the forty-seventh session, supra note 308, at 130.

322. M. Cherif Bassiouni, A DRAFT InTERnational CRIMINAL CODE AND DRAFT STATUTE FOR AN INTERNATIONAL CRIMINAL TRIBUNAL 36 (1987) [hereinafter DRAFT INTERNATIONAL CRIMINAL CODE AND DRAFT STATUTE].

323. Id.

324. Id.

325. Id. at 100 .

326. Gilbert, supra note 264 , at $357,366$.

327. Report on the forty-sixth session, supra note 29 , at 348-49. 
individual acts on a state's behalf, for the same act or omission. State criminal responsibility, of course, ultimately rests upon individual acts and omissions.

Increasingly, domestic laws, for example Anglo-American, attribute criminal responsibility to corporations and other private and public enterprises and institutions through "public welfare offenses" of strict liability; the respondeat superior theory, under which officers' and employees' actions are taken to be those of the organization; and the "organizational fault" concept, which treats as breach of duty of care inadequate policies and practices in such areas as decision-making, supervision and accident prevention. ${ }^{328}$ Such laws are common in the environmental sphere. Their approach has not gained much support at the international level, but could as civil and common law systems converge and in turn influence international law. ${ }^{329}$

In the absence of a tribunal to try international crimes in peacetime, detailed consideration of standing would be unproductive. Aside from the Nürnberg Judgment's implication of individual rights and the Genocide Convention's references to group rights, standing to complain of international crimes is the traditional preserve of states-all states, given the erga omnes character of the obligations breached. The ILC recognizes this and codified it in its Draft Articles on State Responsibility, defining "injured State" in the case of international crime as "all other States."

\section{Ecocide as International Crime}

Ecocide, as here defined, is not recognized as an international crime. Categories of environmental destruction which fit within the definition of ecocide are gaining such recognition, though, as evidenced by the Draft Articles on State Responsibility and the Draft Code of Crimes Against the Peace and Security of Mankind. Furthermore, ecocide in its entirety resembles accepted international crimes in important ways and therefore could, and perhaps eventually will, be accorded that status.

\section{a. Codification}

Article 19 of the Draft Articles on State Responsibility identifies as an international crime the serious breach by a state of an obligation essential for the protection of fundamental world interests, including peace and security,

328. Josephine Kelly, Address at the Australian Centre for Environmental Law (Sept. 1, 1993), in ENVIRONMENTAL CRIME, supra note 47, at 165; Zada Lipman, Address at the Australian Centre for Environmental Law (Sept. 1, 1993) in ENVIRONMENTAL CRIME, supra note 47, at 31; Robert J. Fowler, Address at the Australian Centre for Environmental Law (Sept. 1, 1993), in ENVIRONMENTAL CRIME, supra note 47, at 155.

329. The Nürnberg Charter allows for organizations to be criminally responsible, at least so as to render their members responsible. Nürnberg Charter, supra note 270 , art. 9.

330. Draft Articles on State Responsibility, supra note 79, art. 5(3). 
human rights, and safeguarding and preservation of the human environment. Paragraph 3(d) explicitly identifies as criminal those breaches of international obligations "prohibiting massive pollution of the atmosphere or of the seas." Ecocide's endangerment of international peace and security and infringement of fundamental human rights could be said to meet the conditions of paragraphs 3(a) and (c). All three cases mean the breach of erga omnes obligations through violation of jus cogens. Article 19 equates and links them, which is significant given the view of some ILC members that paragraph 3(d) might be premature in terms of community recognition. ${ }^{331}$ Even if such is the case, ecocide's threats to international peace and security and human rights place it firmly within Article 19's coverage.

We can therefore say that customary international law recognizes at least those instances of ecocide causing "massive pollution of the atmosphere or of the seas." This might currently be limited to breaches of specific treaty commitments. With recognition of ecocide as an international delict based on customary international law, including human rights law, though, a wider range of acts and omissions meeting the conditions of ecocide could be accepted as fitting within paragraph 3(d). As well, customary international law recognizes as international crime deliberate, systematic or widespread programs threatening peace and security or human rights, without excluding as a possibility environmental programs. The examples of ecocide discussed in Section I(A) differ from crimes like aggression and genocide in that the resulting harm is unintentional. Changing attitudes toward the environment, however, could mean that recklessness and negligence come to suffice.

Article 26 of the Draft Code of Crimes Against the Peace and Security of Mankind identifies as an international crime the wilful causing of "widespread, long-term and severe" environmental damage. This comes close to the definition of ecocide, and indeed goes further by applying to individuals and requiring neither international consequences (although they are almost necessarily inferred from the Code's context and purposes) nor the element of waste. On the other hand, criminal responsibility cannot be based on reckless or negligent behavior and does not attach to states; and it appears that activity must be connected to or in execution of war crimes or crimes against peace. Though only certain instances of ecocide would therefore fall within Article 26, it lays the foundation for wider recognition, particularly should the link to war crimes disappear. ${ }^{332}$ This is especially so given the equating by inclusion together of Article 21's crimes against humanity and Article 26. This equation supports the peace and security/human rights links with ecocide identified by this author.

331. See Report on the forty-fifth session, supra note 29, at 49-53 (discussing Article 19).

332. Note the International Court of Justice dictum in Corfu Channel that "elementary considerations of humanity [are] even more exacting in peace than in war." 1949 I.C.J. at 22. 


\section{b. Attitudes}

Global attitudes-a key factor in defining international crime, according to Article 19(2) of the Draft Articles on State Responsibility-are hardening against those who damage the environment. A variety of values including human health and welfare, political and economic stability, species and wilderness preservation, and aesthetics are gaining international acceptance as being sufficiently important to be protected by penal sanctions. "[E]nvironmental vandalism, particularly on a large scale, is becoming more and more seen as a gross social harm worthy of being treated as a "real" criminal offence-and not just when, as in Chernobyl or Bhopal, large numbers of people are killed or injured." 333 Rooted in public nuisance's origins as a crime, municipal criminal and quasi-criminal laws are proliferating to suppress and punish environmental harm in all parts of the world. ${ }^{334}$ These laws both reflect and, as criminalization of such conduct becomes a "general principle of law recognized by civilized nations," support corresponding development of an international crime.

This development is evident in the draft resolution and report of the U.N. Ad Hoc Expert Group on More Effective Forms of International Cooperation Against Transnational Crime, Including Environmental Crime, ${ }^{335}$ considered at the 1994 meeting of the Economic and Social Council's Commission on Crime Prevention and Criminal Justice. Referring to Article 19 of the Draft Articles on State Responsibility, Article 26 of the Draft Code of Crimes Against the Peace and Security of Mankind, and the Vienna Declaration and Programme of Action, the draft resolution recommends municipal criminal legislation, based on the polluter pays and precautionary principles and permitting citizen suits and class actions, against "deliberate, reckless or negligent assaults on the environment that cause or create imminent risks of serious damage, harm or injury."336 The report recommends an international convention covering "the most serious forms of environmental crimes" in terms highly similar to this author's proposals for ecocide: mens rea could be established through intent, recklessness or possibly negligence; actus reus could arise from omissions such as failure to operate industry cleanly, obtain permits or notify authorities of oil spills, nuclear accidents and other mishaps;

333. Goode, supra note 50. The Organization of African Unity declared in 1988 that the dumping of toxic wastes in Africa is a crime against Africa and its people. Govemment of Italy, supra note 62 , at 26.

334. See supra Section II(A). Northern European countries, for example, have criminalized a range of environmentally harmful activities. Heine, supra note 63 , at 110 . In Australia, the New South Wales Land and Environment Court acts as a criminal court.

335. DRAFt Resolution AND REPORT ON THE MEETING OF THE AD HOC GROUP ON MORE EFFECTIVE FORMS OF INTERNATIONAL COOPERATION AGAINST TRANSNATIONAL CRIME, INCLUDING ENVIRONMENTAL CRIME, VIENNA, Dec. 7-10, 1993, U.N. Doc. E/CN.15/1994/4/Add.2 (1993) [hereinafter DRAFT RESOLUTION AND REPORT].

336. Id. at $4-5$.

337. Id. at 6 . 
requisite damage could be to other states or the global environment through short or long term endangerment of water, soil, air or wildlife. ${ }^{338}$ Like this author, the report recognizes that, under current international law, corporate activities must be regulated domestically by states, which are responsible to the international community for doing so.

\section{c. Waste}

International intolerance towards environmental destruction increasingly mirrors the moral outrage underlying the Nürnberg Charter and Judgment. It is submitted that the reason is waste. Perpetrators know or ought to know that their activities infringe rights unnecessarily because alternatives are available. Aside from animal rights supporters, few would share Paul Watson's sentiment that "the Japanese are ecological criminals" ${ }^{1339}$ because of their whaling and fishing practices, as long as those practices were sustainable and efficient, and performed in order to produce essential products which had no appropriate substitutes and were not obtainable through more ecologically sound processes.

Waste is gaining acceptance under international law as an element of what makes environmental destruction "wrong." Paragraph 10 of the World Charter for Nature declares, "Natural resources shall not be wasted . . . ." Articles 61 and 62 of UNCLOS limit coastal states to harvesting the "maximum sustainable yield" of fish, oblige them to allow others access to surpluses, and permit them to enact measures to ensure efficient extraction. The Experts Group on Environmental Law of the WCED proposes, in Article 3 of its Draft Convention on Environmental Protection and Sustainable Development, ${ }^{340}$ that states shall adhere to "the principle of optimum sustainable yield" in exploiting natural resources.

Perpetrators of ecocide rarely intend to waste resources. As with the Apartheid Convention, though, that lack of motive is irrelevant. ${ }^{341}$ Ecocide's illegality results from violations of duty of care and fundamental human rights. The author predicts, however, that the characterization of ecocide as an international crime will arise from moral outrage at the waste it represents. This moral element could help resolve the difficulty of attributing mens rea to states. It will certainly counter LDC arguments that ecocide-type destruction is a necessary aspect of development or, as the U.N. Ad Hoc Expert Group on More Effective Forms of International Cooperation

338. Id. at 10-11.

339. Hinch at Seven: Interview with Paul Watson, Founder, Sea Sheperd Society (Channel Seven Network, Australia, July 25, 1991).

340. EnVIRonmental Protection and Sustainable Development: Legal Principles AND RECOMMENDATIONS (World Commission on Environment and Development ed., 1987).

341. Apartheid Convention, supra note 289, art. 3. 
Against Transnational Crime, Including Environmental Crime put it, "legally sanctioned crime," regarded as the "price of development."

\section{d. Necessity}

Criminalization of ecocide will likely occur not only because of hardened attitudes and moral outrage, but also because it may ultimately be necessary. Bassiouni writes that it is characteristic of international crime that international cooperation is required to prevent, suppress and control it. ${ }^{343}$ This requirement of international cooperation is an aspect of ecocide's international character, described in Section I(A)(2). Just as publicists deemed nuclear weapons illegal during the Cold War, not merely on moral grounds but because they threaten civilization, ${ }^{344}$ they will argue-correctly, in this author's opinion-that ecocide must be outlawed by the international community in the interest of its survival.

\section{CONCLUSION}

This Article proves the existence and ongoing evolution of an international delict, ecocide: the breach of an erga omnes duty of care by states, and arguably individuals and organizations, which deliberately, recklessly or negligently cause or permit serious environmental harm. The duty of care arises from a combination of international environmental law and human rights law, based on treaties, customary international law, "general principles of law recognized by civilized nations," judicial decisions, publicists' writings, and soft law declarations and resolutions. As these sources of law develop and the concept of ecocide gains recognition, the restrictions outlined in Section I will give way, and less serious acts and omissions, a wider range of perpetrators, and new rights and interests will be brought within ecocide's purview. In particular, acknowledgement of non-human rights, such as that of other species to exist, will broaden standing.

The Article also establishes that ecocide could be considered an international crime, indeed that certain instances of commission are achieving that status. Criminalization of ecocide will occur because it must. As Bassiouni writes, "the object of the normative proscription of international criminal law is to specify conduct identified as harmful to a given world social interest whose protection is deemed to require the imposition of criminal sanctions on violators and which sanctions are enforced by the member states of the world community through international collective, cooperative or national ac-

342. DRAFT RESOlUtion AND REPORT, supra note 335, at 11.

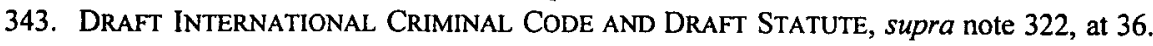

344. WEERAMANTRY, supra note 263 , at 79. 
tion."345 Despite its reluctance to create new international crimes, a reluctance justified by the absence of enforcement machinery, the international community will soon realize that ecocide so menaces fundamental human rights and international peace and security that it must be treated with the same gravity as apartheid or genocide. Precise standards of causation, damage and culpability, and institutions to prosecute and punish offenders, will follow.

It is not the author's purpose to propose or speculate upon standards and institutions. They are secondary to the more important work of establishing the underlying principles and proving that ecocide is wrong under international law. Having done so, the author is content to have helped shift the onus from conservationists, who have long had to convince authorities that "development" is not always progress, to developers, who will increasingly have to show why it is. To avoid the charge that they are committing ecocide, those who alter and affect ecosystems will have to demonstrate that the benefits truly outweigh the costs-that the activity is not wasteful. Recognition of ecocide may not immediately, or ever, lead to an international criminal or environmental court. Perhaps enforcement will mean improved municipal regulation, and cooperation between developed and developing countries through debt relief, ESD-guided aid and investment policies, and technology transfer on concessional terms in return for environmental impact assessment, community involvement in planning decisions and protection of biological diversity.

Ecocide could thus become a catalyst for acceptance of third generation rights, and the bridging of values promoted by Western countries-respect for life and individual liberties, responsibility for one's actions and conservation-and those associated with the East and South - the importance of harmony and the community, duty, and improved standards of living. This culmination, to which we must aspire, would represent the ultimate victory of international law. We must succeed in balancing and guarding these values. Our survival as a species, and our conviction that "humanity" connotes reason and benevolence, depend upon it.

345. M. ChERIF Bassiouni, InTERnational CRIMINAL LaW: A Draft INTERNATIONAL Criminal Code 1 (1980). 
California Western International Law Journal, Vol. 26, No. 2 [1996], Art. 3 